Florida International University FIU Digital Commons

6-22-2018

\title{
How Does the Nature of Accounting Standards Affect Audit Quality and Earnings Attributes?
}

Ran Ling

Florida International University, rling005@fiu.edu

DOI: $10.25148 /$ etd.FIDC006871

Follow this and additional works at: https:// digitalcommons.fiu.edu/etd

Part of the Accounting Commons

\section{Recommended Citation}

Ling, Ran, "How Does the Nature of Accounting Standards Affect Audit Quality and Earnings Attributes?" (2018). FIU Electronic Theses and Dissertations. 3764.

https://digitalcommons.fiu.edu/etd/3764

This work is brought to you for free and open access by the University Graduate School at FIU Digital Commons. It has been accepted for inclusion in FIU Electronic Theses and Dissertations by an authorized administrator of FIU Digital Commons. For more information, please contact dcc@fiu.edu. 


\title{
FLORIDA INTERNATIONAL UNIVERSITY
}

\author{
Miami, Florida
}

\section{HOW DOES THE NATURE OF ACCOUNTING STANDARDS AFFECT AUDIT QUALITY AND EARNINGS ATTRIBUTES?}

A dissertation proposal submitted in partial fulfillment of

the requirements for the degree of

DOCTOR OF PHILOSOPHY

in

BUSINESS ADMINISTRATION

by

Ran Ling

2018 
To: Dean Joanne Li

College of Business

This dissertation, written by Ran Ling, and entitled How Does the Nature of Accounting Standards Affect Audit Quality and Earnings Attributes, having been approved in respect to style and intellectual content, is referred to you for judgment.

We have read this dissertation and recommend that it be approved.

Xiao Chuan Huang

Jonathan Milian

Wen-Hsiu Chou

Steve Wen-Jen Lin, Major Professor

Date of Defense: June 22, 2018

The dissertation of Ran Ling is approved.

Dean Joanne Li
College of Business

Andrés G. Gil

Vice President for Research and Economic Development and Dean of the University Graduate School

Florida International University, 2018 
(C) Copyright 2018 by Ran Ling

All rights reserved. 


\section{DEDICATION}

I dedicate this dissertation to my mother. Without her understanding, support, and most of all love, the completion of this work would not have been possible. 


\section{ACKNOWLEDGMENTS}

I would like to express my deep gratitude and thanks to my major professor, Dr. Steve Lin, for his dedication, guidance and enthusiasm in helping me to develop my proposal and making this dissertation possible. I like to thank the members of my committee for their patience and encouragement. Their guidance and support has been most appreciated. I wish to give thanks to my friends, Eric and Shawn, whose support was essential to my completion of this dissertation. I would also like to thank

my fellow graduate students in the accounting program for their camaraderie and support. 


\section{ABSTRACT OF THE DISSERTATION \\ HOW DOES THE NATURE OF ACCOUNTING STANDARDS AFFECT \\ AUDIT QUALITY AND EARNINGS ATTRIBUTES? \\ by \\ Ran Ling}

Florida International University, 2018

Miami, Florida

\section{Professor Steve Wen-Jen Lin, Major Professor}

The purpose of this study is to provide evidence on the effects of the nature of accounting standards (i.e. principles- versus rules-based accounting standards) on audit quality and earnings attributes. I construct a comprehensive instrument to effectively measure rulesbased characteristics in the U.S. GAAP following Mergenthaler (2011). I then construct a firm-level instrument to capture firms' reliance on principles-based accounting standards using the textual analysis approach developed by Folsom et al. (2017). Using data from S\&P 500 companies during 2009-2014, I first examine whether principles- (or rules-) based standards in the FASB Accounting Standards Codification (ASC) system affect both the inputs (i.e. audit fees) and the outcomes (i.e. financial misstatements) of the audit process. The multivariate regression results show that firms applying more principles-based standards pay less audit fees but the nature of accounting standards doesn't affect restatements. My finding suggests that auditors do consider the degree of precision and complexity in accounting standards when assessing the level of audit inputs, but audit quality is generally not compromised by the nature of accounting standards. I also investigate the influence on firms' earnings attributes. More specifically, I examine the statistical association between firms' reliance on principles- (or rules-) based accounting 
standards and the timely loss recognition (TLR) during the same sample period. Interestingly, I find that the timeliness in loss recognition is insensitive to firms' choice of applying more principles- (or rules-) based accounting standards. The results of this study should be of interest to preparers, auditors, U.S. standards setters, and accounting researchers. 


\section{TABLE OF CONTENTS}

CHAPTER

PAGE

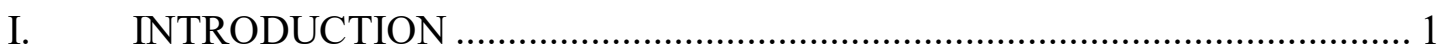

II. ITERATURE REVIEW ...................................................................... 8

II.1 Nature of Accounting Standards ................................................ 8

II.1.1 Principles-Based Accounting Standards ......................... 9

II.1.2 Rules-Based Accounting Standards ............................... 11

II.2 Why Does U.S. GAAP Contain More Rules-Based Standards? ........ 13

II.3 Converging to a More Principles-Based System............................. 15

III. HYPOTHESIS DEVELOPMENT....................................................... 16

IV. RESEARCH DESIGN AND SAMPLE SELECTION ................................. 20

IV.1 Rules-Based Continuum $(R B C)$ Measure .................................... 20

IV.2 Principles-Based Score (PSCORE) Measure ................................... 21

IV.2.1 Identifying the Keyword List........................................ 21

IV.2.2 Relative Importance (REL_IMP) Measure ...................... 23

IV.2.3 Firm-Level PSCORE Measure ....................................... 24

IV.3 Research Models and Key Variables ........................................ 25

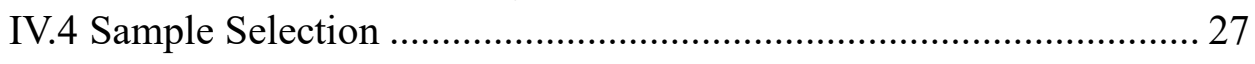

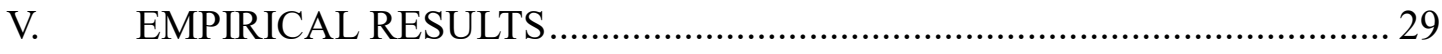

V.1 Descriptive Statistics.............................................................. 29

V.2 Regression analyses ................................................................. 31

VI. CONCLUSIONS, CONTRIBUTIONS, AND LIMITATIONS ..................... 33

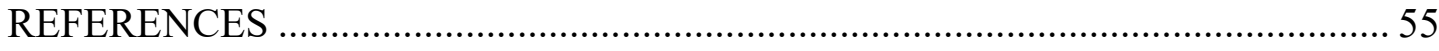

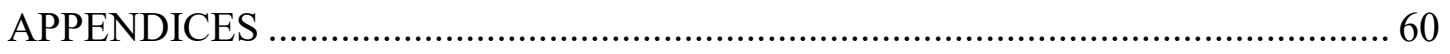

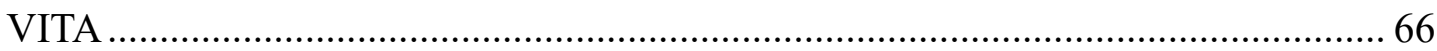




\section{LIST OF TABLES}

TABLE

PAGE

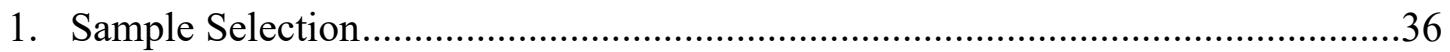

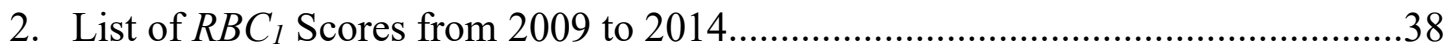

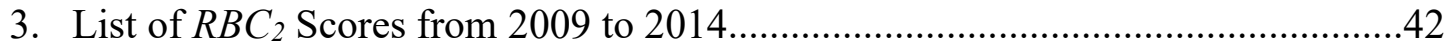

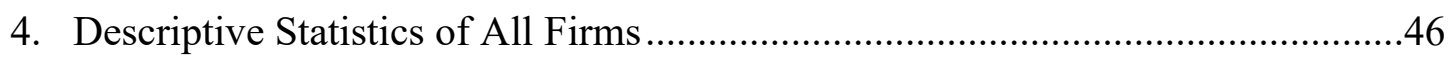

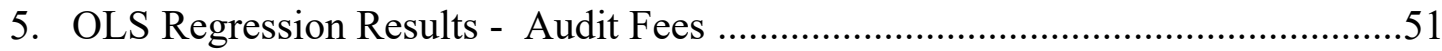

6. OLS Regression Results - Restatements ......................................................52

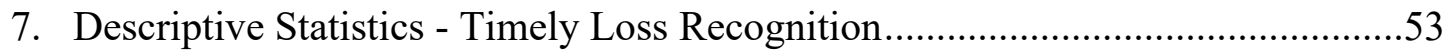

8. OLS Regression Results - Timely Loss Recognition .........................................54 


\section{LIST OF FIGURES}

\section{FIGURE}

PAGE

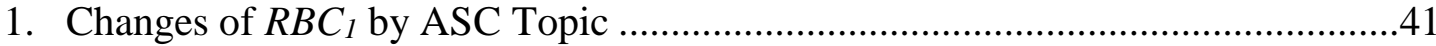

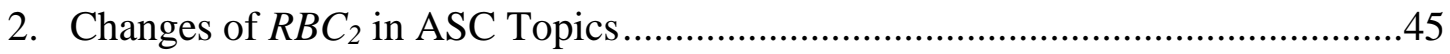

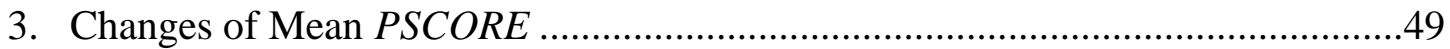

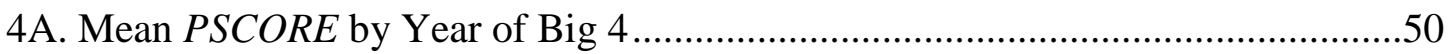

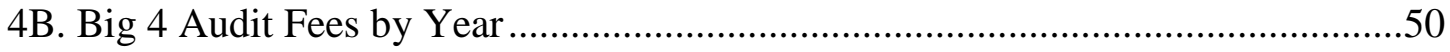




\section{INTRODUCTION}

In this study, I examine how the nature of U.S. accounting standards affects audit quality and earnings attributes. The nature of accounting standards can be best characterized as a spectrum ranging from conceptual principles-based to detailed rulesbased (SEC 2003; Cunningham 2007). To distinguish between the two extremes in accounting standards, people consider accounting treatments under principles-based standards aiming to capture the underlying economic substance of transactions whereas those under rules-based standards emphasizing more on the degree of precision or the complexity (e.g., Kaplow 2000; Schipper 2003; Maines et al 2003). However, in practice, a "standard" is usually a combination of both principles and rules that apply to a certain accounting issue. ${ }^{1}$

U.S. accounting standards are widely recognized as being constructed upon a set of principles derived from the FASB's Conceptual Framework. However, due to the existence of a strong legal regime (e.g. high litigation risk) and the presence of complexity in accounting issues (e.g. fair value measurement), various "rules-based" elements such as scope exceptions and detailed implementation guidance lead the U.S. GAAP to become rules-oriented (Schipper 2003). Even though U.S. GAAP is considered as a high-quality accounting system given the political, institutional, and cultural factors (La Porta et al. 1998, Ball et al. 2000, Ball et al 2003, Leuz et al. 2003), concerns arise that U.S. accounting standards have become heavily skewed towards the rules-based end of the spectrum (Schipper 2003, FASB 2002, and Nobes 2004), and even more rules-based over time (Mergenthaler 2011). In response to the difficulties facing U.S. financial reporting

\footnotetext{
${ }^{1}$ As the SEC classified, U.S. GAAP and IFRS contain both principles- and rules- based standards although it is widely believed that U.S. GAAP are more rules based than IFRS.
} 
environment since the corporate accounting scandals in early 2000s, U.S. standard setters initiated a shift to a more "principles-based" financial reporting system and proposed a possible adoption of IFRS which are commonly perceived in the accounting literature to be more principles-based standards (the Sarbanes-Oxley Act, 2002). Although the SEC staff report in 2012 noted several irreconcilable fundamental differences between U.S. GAAP and IFRS and implicitly expressed the SEC's decision not to adopt IFRS, the debate over the cost-benefit economic analysis of the implementation of a principles-based system has continued.

On the one hand, principles-guided standards focus on the nature and purposes of firms' economic transactions and provide general guidance on how to fairly account for and report these transactions in financial statements. Hence, they require preparers (i.e. managers) to exercise high-level professional judgment and expertise and allow preparers to accommodate the specifics of an economic transaction (Maines et al. 2003, Nobes 2004). However, principles-based accounting system per se may not guarantee higher accounting quality for some reasons. First of all, it leaves room for different preparers' interpretations, resulting in potential lack of comparability between financial reports. Secondly, principlesbased standards may tolerate too much discretion where managers could exercise their judgment opportunistically to manipulate earnings or hide information to achieve desired outcomes such as maximizing compensation, circumventing debt covenant violations, and avoiding stock price declines (e.g. Healy and Wahlen 1999, Dechow and Skinner 2000). Moreover, it is also costly for auditors and enforcement agencies to understand and decide whether firm-specific interpretations are presented correctly (e.g. Herz 2003). 
On the other hand, U.S. GAAP contains specific criteria, "bright-line" thresholds, examples, scope exceptions, subsequent precedents, and implementation guidance (FASB 2002; Nelson 2003; Schipper 2003; SEC 2003). These characteristics increase the precision and complexity of an accounting standard extensively. Features such as bright lines and high-level details provide greater specificity and clarity on accounting for particular transactions. Therefore, rules-based standards increase communication accuracy and eliminate managerial opportunistic activities that lead to aggressive reporting choices (Nelson 2003). Opponents, on the contrary, argue that rules-based characteristics often provide safe harbors to managers because detailed guidance and alternatives make it harder to differentiate between an innocent misapplication of GAAP and an intentional violation. That's why managers are more likely to attempt earnings management through transaction structuring under rules-based standards (Nelson et al. 2002). Secondly, since rules-based characteristics demand less use of professional judgment, critics concern that auditors could just follow "check the box" mentality as long as the rules fall within their literal scope regardless of their intent and purpose. Lastly, the emphasis on detailed guidance not only delays timely reporting but is also deemed as a form of insurance against lawsuits, where compliance with rules is perceived to provide a defense against allegations of negligence or fraud (Maines et al 2003; Melone 2004).

Prior research in economics and accounting has provided evidence, especially on managers' incentives for earnings management, that varying levels of rules-based characteristics affect individuals' behavior differently over the degree to which people consider themselves to be punished from violating a rule (Kaplow 2000, Nelson et al. 2002). For example, a survey study conducted by Nelson et al. (2002) indicates that 
managers align their earnings management strategies with corresponding accounting standards (whether the standards are principles- or rules- based) to minimize auditors' inquiry and public scrutiny while the auditor's incentives also vary with the applicable standards. However, little empirical evidence is available in the literature on whether decision makers alter their behavior depending on the precision and complexity of relevant accounting standards. One reason is the lack of appropriate approach to capture principlesvs. rules-based characteristics in accounting standards. The existing studies are mostly operationalized in experimental setting where rules-based features are manipulated by whether the standard contains "bright-line" thresholds in the case of lease classification (Agoglia et al. 2011, Collins et al 2012).

To identify principles- (or rules-) based characteristics in U.S. GAAP, I employ the rules-based continuum (RBC) measure following Mergenthaler (2011). RBC scores effectively capture rules-oriented features contained in each U.S. accounting standard. But not every standard is necessarily applicable to each firm. Companies adopt appropriate standards depending on the nature of the businesses and various transactions involved. Thus, to capture firms' reliance on principles- (or rules-) based standards, I construct a firm-level instrument, PSCORE, using the textual analysis approach developed by Folsom et al. (2017). Practically, I compile a keyword list for each FASB Accounting Standards Codification (ASC) topic and then count the number of times these keywords appear in companies' $10-\mathrm{K}$ filings. ${ }^{2}$ PSCORE is the result from mapping the RBC scores to keyword counts in firms' annual reports. This process determines what pertinent standards each firm is complying with and reveals the influence of the standards. Also, this study constructs

\footnotetext{
${ }^{2}$ I also consider standard amendments in the Accounting Standards Update (ASU) every year during the sample period.
} 
PSCORE in the way that a higher PSCORE indicates more use of principles-based standards in a firm's financial statements.

This study uses audit fee and financial restatement as proxies for audit quality while earnings quality is measured by the timely recognition of economic losses. These variables are widely used in the literature to investigate audit and earnings quality, respectively. Using S\&P 500 firms during the sample period between 2009-2014, my results show that the average PSCORE of my sample firms dropped after 2009, indicating firms were complying with less principles-based standards. Later, it holds relatively stable from 2011 to 2013 with a slightly increase in 2014. Such increase in PSCORE suggests that firms are actually applying more principles-based standards despite the fact that standards are becoming more rules-oriented. In the analysis of the PSCORE among Big 4 audit firms, I also find that companies audited by KPMG or Ernst \& Young rely more on the principlesbased standards, and more importantly, they pay less audit fees, while Deloitte and PricewaterhouseCoopers tend to have their clients applying more rules-based standards and charge higher audit fees. ${ }^{3}$

I first examine whether principles- (or rules-) based standards in the U.S. GAAP affect both inputs (i.e. audit fees) and outcomes (i.e. financial misstatements) of the audit process. ${ }^{4}$ The multivariate regression results show that PSCORE is negatively associated with the audit fees but not related to restatements, suggesting that auditors do consider the degree of precision and complexity in accounting standards when assessing the level of

\footnotetext{
${ }^{3}$ This study does not examine whether auditors are principles- (or rules-) based. Future research may investigate the dynamics between principles- and rules- based standards and auditors.

4 Audit input includes auditors' evaluation of audit risk and auditors' effort to audit clients' financial statements. In other words, audit input is more about audit fee. In contrast, audit outcome is more about audit quality. This study uses financial statement restatement as a proxy for audit quality.
} 
audit inputs, but the nature of accounting standards doesn't appear to have affected the outcome of audit process. Principles-based standards focus on the economic substance instead of legal form of transactions and involve significant professional judgment and greater expertise. Hence, these standards should lead to higher accounting quality (Folsom et al. 2017), which in turn has a lower audit risk. However, principles-based standards heavily rely on managerial discretion, which may be used by managers for opportunistic activities, and increase audit risk. Moreover, Donelson et al (2012) documents that financial statement restatements associated with principles-based standards are more likely to involve accounting litigation. In other words, firms that use more principles-based standards have higher audit risk in general. Auditors therefore have to trade off the cost and benefit of principles- based standards and evaluate their potential net effects on audit risk. My finding supports the notion that auditors perceive firms that use more principlesbased standards to have lower audit risk compared to firms that use more rules-based standards. As a result, auditors charge less audit fees to firms that use more principlesbased standards. To my best knowledge, this finding is new in the literature.

Financial statement restatements have been widely used as a proxy for poor audit quality. It is not clear in the literature as to whether principles- (or rules-) based standards are more likely to trigger financial statement restatements. On the one hand, principlesbased standards significantly rely on managerial professional judgement and expertise, managerial discretion plays an important role in determining accounting quality, which in turn affects audit quality. Hence, principles-based standards may trigger more restatements if managers abuse their judgement or discretion. On the other hand, principles-based standards allow managers to reflect the economic substance of transactions, which should 
increase accounting quality and reduce audit risk. Hence, these standards may reduce financial statement restatements. My finding suggests that although auditors perceive firms using more principles-based standards to have lower audit risk and charge less audit fees compared to firms using more rules-based standards, audit quality is generally not compromised by the nature of accounting standards. This finding is also new to the literature.

I also investigate the influence of principles- vs. rules-based accounting standards on firms' earnings attributes. More specifically, I examine the statistical association between firm-level PSCORE and the timeliness in loss recognition during the same sample period. Timely recognition of economic losses has been widely used in the literature as a proxy for accounting quality. More (less) timely recognition of economic losses is regarded as a proxy for high (low) quality earnings. Folsom et al. (2017) find that principles-based accounting standards are associated with higher accounting quality, measured by value relevance, frequency of meeting and beating analysts' forecasts, small positive earnings, and discretionary accruals. However, they do not investigate whether PSCORE is also associated with the timeliness in loss recognition. I investigate this issue to fill the gap in the literature. I predict that principles-based standards should improve timely loss recognition because these standards emphasize on economic substance instead of legal form of transactions. Interestingly, I find that PSCORE doesn't impact on timeliness in loss recognition, indicating that timeliness in loss recognition is insensitive to firms' choice of applying more principles- (or rules-) based accounting standards.

The remainder of the proposal proceeds as follows: Section 2 summarizes related literature in accounting standards and Characteristics in U.S. GAAP. Section 3 develops 
hypotheses on the nature of U.S. accounting standards on audit quality and earnings attributes. Section 4 describes research design and data selection. Section 5 depicts descriptive statistics and provides empirical evidence. The final section concludes and discusses contributions and limitations.

\section{LITERATURE REVIEW}

\section{II.1 Nature of Accounting Standards}

Accounting standards are viewed as the regulatory devices of accounting. They are essential to the efficient functioning of the economy, where decisions about the allocation of resources by investors, creditors, and other users rely heavily on financial information that must be relevant, reliable, comparable, and consistent (Concept Statements, FASB, 1978). It is commonly considered that financial accounting standards lie on a spectrum between conceptual principles and detailed rules. Many studies argue that principlesguided standards capture the economic substance of transactions whereas rules-based standards emphasize more on the degree of precision or the complexity they embody (e.g., Kaplow 2000; Schipper 2003; Maines et al 2003). Therefore, a "standard" alone is a combination of principles and rules that apply to a certain accounting issue. ${ }^{5}$

The debate over the merits of principles-based versus rules-based standards has continued and is well documented in the literature. For instance, Maines et al (2003) argue that principles based standards are like two sides of a sword. On the one hand, they help

\footnotetext{
${ }^{5}$ Prior studies document that both IFRS and U.S. GAAP contain principles and rules based standards. For example, Donelson et al (2016) show that under IFRS both accounting for "Consolidation" (IAS 27) and "Leases" (IAS 17) are more principle-based standards while both lie towards the rules-based end under U.S. GAAP (ARB51 and SFAS 13, respectively). Nevertheless, IFRS identifies accounting for "Inventory" (IAS 2), "Interest capitalization" (IAS 23), "Asset retirement obligation" (IAS 37), and "Exit or disposal costs (restructuring)" (IAS 37) as more rules-oriented than U.S. GAAP does (ARB43_4, SFAS 34, SFAS 143, and SFAS 146, respectively).
} 
reflect economic substance of transactions; on the other hand, they avoid it. Schipper (2003), however, argue that rules-based standards are likely to lead to more comparable and consistent financial statements. However, studies cannot reach a uniform conclusion which one is better than the other. To find optimal design of standards, for example, Gao et al (2017) examine the trade-offs between principles-based versus rules-based standards. They show that the optimal standard must necessarily contain both principles-based and rules-based elements because a rules-based standard induces evidence management (transaction structuring) whereas a principles-based induces abusive exercise of discretion.

\section{II.1.1 Principles-Based Accounting Standards}

Written in clear, concise and plain language, principles-based standards provide users guidance with broad concepts and principles that aim to capture the underlying economics of transactions. They are also believed to better communicate users' needs for clarity and transparency (DiPiazza et al. 2008). To improve the relevance and usefulness of financial reporting information, principles-based standards allow managers to accommodate the specifics of a transaction. Instead of seeking to identify the rule that directs how to record a transaction or make a disclosure, preparers pay more attention on the appropriate exercise of professional judgment and greater expertise, and, therefore, leading to higher earnings quality (FASB 2002; SEC 2003). For instance, Barth et al (2008) find firms that voluntarily adopt more principles-based standards such as IAS are associated with higher accounting quality (e.g. less earnings management, more timely loss recognition and more value relevance of earnings). Consistently, Folsom et al. (2017) find that firms using more principles-based standards are positively associated with higher 
earnings informativeness, persistence, and predictability of future cash flows. It is also believed that under principles-based accounting standards, auditors are motivated to think deeply and understand all possible perspectives of the accounting issues, and to evaluate information thoroughly (Peytcheva et al 2014).

However, principles-based accounting standards per se may not guarantee higher accounting quality. Instead, the mindset of managers, audit committee members, and auditors must also possess both expert judgment and a desire for unbiased reporting under principles-based standards in order to reflect underlying economics of transactions (Maines et al 2003). For example, Jamal and Tan (2010) find that less aggressive reporting under principles-based standards exists only when the auditor is principles-oriented. Grenier et al (2015) also demonstrate that the efficacy of audit firm efforts depends on the precision of accounting standards, where increased litigation exposure under principles-based standards is manageable if audit firms can provide credible evidence to defend their professional judgments.

On the other hand, critics argue that principles-based standards leave room for different interpretations by preparers, leading to lower consensus among practitioners and potential lack of comparability between financial reports. For instance, Amer et al. (1994) find relatively high variance in audit managers' interpretations of probability threshold, indicating standards sometimes are interpreted differently than intended in a given context. Prior research has shown principles-based standards provide too much discretion that could be exploited by management. Managers, at times, exercise their judgment opportunistically to manipulate earnings or hide information to achieve desired outcomes such as maximizing compensation, circumventing debt covenant violations, and avoiding stock 
price declines (e.g. Healy and Wahlen 1999, Dechow and Skinner 2000). Moreover, with little guidance or structure provided on how to exercise professional judgment, it is also costly for auditors and enforcement agencies to understand and decide whether firmspecific interpretations are presented correctly (Herz 2003). Consistent with this argument, Nelson et al. (2002) also find that auditors often compromise in client negotiations about managements' interpretations when the standard is imprecise (principles-based).

\section{II.1.2 Rules-Based Accounting Standards}

Characteristics of rules-based standards are generally described as standards that contain bright lines, examples, scope exceptions, and implementation guidance (FASB 2002; Nelson 2003; Schipper 2003; SEC 2003). Such features extensively increase the precision and complexity of an accounting standard. Proponents claim that features such as "bright-line" thresholds and a high level of detail provide greater specificity and clarity on accounting for particular transactions. Therefore, rules-based standards increase communication accuracy and eliminate managerial opportunistic activities that lead to aggressive reporting choices by management (Nelson 2003). Schipper (2003) also points out that detailed guidance can potentially reduce after-the-fact disputes with the SEC of interpreting managements' judgments and increase financial statement comparability and verifiability. Consistently, Boone et al. (2013) document that the SEC is more likely to comment on a registrant's accounting if a standard is more rules-based.

There is little empirical research that examines whether decision makers alter their behavior depending on the precision and complexity of relevant accounting standards. ${ }^{6}$

\footnotetext{
${ }^{6}$ Many studies in this area are performed in behavior analyses.
} 
One reason for scarce empirical evidence in the literature is due to the lack of appropriate approach to capture rules-based characteristics in accounting standards. The existing experimental studies mostly operationalize rules-based standards by manipulating whether the standard contains bright-line thresholds. For example, Agoglia et al. (2011) find that CFOs are less likely to report aggressively (i.e., classifying leases as operating) when standards are principles-based. Consistently, Collins et al (2012) provide strong evidence that U.S. GAAP firms applying accounting for leases that contains bright-line guidance (i.e., ASC 840) are more likely to classify leases as operating than IFRS firms applying accounting for leases that does not contain bright line guidance. Kadous and Mercer (2012) find that rules-based characteristics can influence jury awards in lawsuits against auditors depending on the aggressiveness of financial reports and on the industry reporting norm.

However, some articulate that rules-based characteristics offer safe harbors to corporate managers. Specifically, Nelson et al. (2002) find managers are more likely to attempt earnings management via transaction structuring under rules-based standards where detailed guidance and alternatives make it harder to differentiate between an innocent misapplication of GAAP and an intentional violation. For example, Imhoff and Thomas (1988) provide evidence that managers responded to the precise criteria contained in SFAS No. 13 by structuring lease arrangements to qualify for operating lease treatment. In addition, rules-based characteristics decrease the use of professional judgment. They allow auditors just to follow "check the box" mentality when detailed rules fall safely within their literal scope yet put aside the intent and purpose of the rules. Nelson et al. (2002) find auditors are less likely to challenge transactions structuring under rules-based standards. Moreover, the emphasis on detailed guidance not only delays timely reporting 
but also is deemed as a form of insurance against lawsuits, where compliance with rules is perceived to provide a defense against allegations of negligence or fraud (Maines et al 2003; Melone 2004). Consistently, Mergenthaler (2011) finds the SEC is less likely to penalize a rules-based GAAP violation. Donelson et al. (2012) provide evidence that restatements related to rules-based standards are less likely to result in a litigation, indicating rules-based standards shield firms from potential litigation actions. ${ }^{7}$

\section{II.2 Why Does U.S. GAAP Contain More Rules-Based Standards?}

Since the purpose of this study is to investigate the extent to which principles- (or rules-) based standards in US GAAP have implication for audit and accounting quality, it is important to briefly summarize the historical development of U.S. GAAP. This helps us understand why U.S. GAAP contains more rules-based standards compared to IFRS.

Established in 1973, FASB is designated to govern U.S. accounting practices for public and private companies and not-for-profit organizations that follow GAAP. To accomplish its mission that "to establish and improve standards of financial accounting and reporting for the guidance and education of the public, including issuers, auditors, and users of financial information", FASB has been dedicated to "improve the usefulness of financial reporting by focusing on the primary characteristics of relevance and reliability and on the qualities of comparability and consistency" (FASB 1973). U.S. accounting standards are generally recognized as being constructed upon a set of broad principles derived from the

\footnotetext{
7 They propose two competing theories related to litigation under rules-based standards. One is the "protection" theory where rules-based standards shield firms from litigation so that firms are less likely to be sued or less likely to lose the case. Another is the "roadmap" theory, contending that the specificity of rulesbased standards provides a clear path to successful litigation so plaintiffs are more likely to file a suit or win the case. Their evidence supports the protection theory that rules-based standards appear to act as a safe harbor to shield firms from litigation.
} 
FASB's Conceptual Framework. The framework is useful to establish reasonable bounds for judgment in preparing financial information and to increase understanding of, and confidence in, financial information on the part of users of financial reports (FASB 2007). It also helps the public to understand the nature and limitations of information. For example, FASB Concepts Statements No. 4, Objectives of Financial Reporting by Nonbusiness Organizations; No. 5, Recognition and Measurement in Financial Statements of Business Enterprises; No. 6, Elements of Financial Statements, No. 7, Using Cash Flow Information and Present Value in Accounting Measurements; and No. 8, Conceptual Framework for Financial Reporting-Chapter 1, The Objective of General Purpose Financial Reporting, and Chapter 3, Qualitative Characteristics of Useful Financial Information. These accounting concepts set forth fundamentals on which accounting standards are based and provide a frame of reference to resolve accounting issues.

On the other hand, FASB creates standards for financial reporting as well as provides guidance on implementation of standards. In order to increase financial statement comparability and consistency, some "rules-based" features such as treatment and scope exceptions and detailed implementation guidance were then added to U.S. GAAP (Schipper 2003). She points out that scope exceptions and alternative treatments that deviate from the underlying principle of the standard to allow alternative accounting treatment for specific situations. Thus, they add to the length and complexity of the standards and subsequent implementation guidance. Transition exceptions, another rulesbased feature, highlights how U.S. GAAP changes over time by addressing the transition from an old standard to a new standard. Implementation guidance increase comparability 
and verifiability and reduce the incidence of earnings management by increasing the consensus about interpretations or measurements in professional judgment.

To further examine why U.S. GAAP is more rules-based, Donelson et al. (2016) find that among five possible theories litigation risk and complexity in accounting issues influenced the development of rules-based accounting standards the most. With the existence of a strong legal regime in the U.S., complex transactions and complexity in accounting issues such as fair value measurement as well as the demand for rules-based standards are likely to persist.

\section{II.3 Converging to a More Principles-Based System}

Concerns arise when U.S. accounting standards have become more rules-driven over the years. "Overloaded" standards are excessively complex and make it increasingly difficult for practitioners to understand. While legislatures set standards residing more toward the rules-based end of the spectrum, accounting failures such as Enron and WorldCom in early 2000s magnify the importance of informed professional judgment and expertise for implementation of standards. The urge for such reform in U.S. accounting standards on the adoption of a principles-based accounting system was soon reflected as a result of the "Norwalk Agreement" announced by the FASB and the International Accounting Standards Board (IASB) in October 2002. Shortly after, the SEC submitted a study in July 2003 that recommends U.S. accounting standards move toward a principlesbased regime. The discussion has been continuously brought up that whether U.S. GAAP should be led to the direction of more principles-based so as to focus on underlying economics of transactions and events, thereby improving the quality of financial reporting. 
More attention is paid when the SEC expressed strong support to converge U.S. GAAP with international accounting standards in its "Roadmap for the Potential Use of Financial Statements Prepared in Accordance with International Financial Reporting Standards by U.S." (SEC, 2008). ${ }^{8}$

However, due to several irreconcilable fundamental differences between U.S. GAAP and IFRS, mainly the regulatory or legal environment (the presence of complex transactions or high litigation risk), the SEC decided to move away from the idea of convergence with IFRS (SEC Staff Report 2012). U.S. GAAP contains much industry guidance and exceptions that are needed for sound financial reporting in the U.S. landscape due to a more litigious culture that the U.S. financial reporting system cannot function over the long run without clean unambiguous standards or precise guidance (FASB 2012).

\section{HYPOTHESIS DEVELOPMENT}

The majority of the extant literature examine the influence of principles- and/or rules- based standards on firms' financial reporting decisions. Little empirical research has been conducted on whether the nature of standards affect auditor decision-making and audit quality, although the link between audit quality and financial reporting quality has been well established in the prior literature (e.g., Barton, 2005; Ashbaugh et al. 2003). Research on auditors is motivated by the assumption that they provide a useful service demanded across investors. Auditor needs to determine whether information reported in

\footnotetext{
${ }^{8}$ Short-term convergence projects such as "fair value option for financial instruments" and "research and development" as well as major joint projects for example "business combinations" and "fair value measurement" were completed. Project milestones such as the elimination of the reconciliation requirement are also achieved over the years. Moreover, accounting standards for "revenue recognition", "leases", along with other topics that identified as major joint projects have been recently amended in U.S. Accounting Standards Codification.
} 
financial statements is reasonable and whether the reporting choice is appropriate for a particular transaction. High audit quality increases the credibility of the financial reports through greater assurance that the financial statements faithfully represent the firm's underlying economic substance (Dechow et al. 2010). Similarly, Kim et al (2012) find increased financial reporting quality through the adoption of IFRS has led to higher audit fees in EU countries. However, concerns articulate that increased reliance on professional judgment from principles-based standards makes it more difficult and costly to detect violations. Nelson et al (2002) find auditors often compromise in client negotiations in principles-based accounting standards. Sennetti et al (2011) document that jurors evaluate auditors more negatively if auditors have relied on a principles-based accounting standard, even if this standard is properly applied. Cohen et al (2013) provide indirect evidence that auditors are more likely to constrain aggressive reporting when standards are principlesbased under both stronger (U.S.) and weaker regulatory regimes. Another study by Peytcheva et al (2014) propose a theoretical model that principles-based accounting standards increase auditors' expectation of having to justify to others the decision process used, regardless of the outcome of the decision.

However, there is no direct empirical study that examines how the nature of accounting standards may affect auditor's assessed audit risk. To fill up this gap, I look into audit quality from both the audit inputs and the outcomes. In the first test, I examine the association between audit inputs and the precision and complexity of relevant accounting standards. Namely, whether auditors spend more time and efforts on audit engagements when clients apply more principles-bases accounting standards. Audit inputs such as time and efforts are proxied by audit fees as they are not directly observable. On 
the one hand, auditors may charge higher audit fees to mitigate increased level in engagement risk because the application of principles-bases standards demands more professional judgment and greater expertise. On the other hand, using more principlesbased standards are likely to increase accounting quality because auditors and managers need to consider the economic substance of transactions. So, it could reduce audit fees (Kim et al. 2012). Taken together, I propose the first hypothesis in the null form as follows.

\section{H1: There is no association between firms applying more principles-based} standards and audit fees.

Audit inputs may or may not completely translate into audit outcomes. Restatements, as an outcome of the audit process, are one of the most commonly used proxies to measure actual audit quality in the literature. Accounting restatements occur when the auditor erroneously issued an unqualified opinion on materially misstated financial statements. For example, restatements are used to examine whether audit quality is associated with auditor independence, audit committee characteristics, and auditor industry specialization (e.g. Kinney Jr. et al. 2004, Abbott et al. 2004, Agrawal and Chadha 2005, Archambeault et al. 2008, Chin and Chi 2009).

Yet, no empirical work explores whether principles- (or rules-) based standards affects the outcome of audit process in the presence of accounting misstatements. Caplan and Kirschenheiter (2004) find auditors prefer bright-line standards if auditor expertise is unobservable to investors and the average level of auditor expertise increases under brightline standards. In case of observable expertise, expert auditors prefer principles-based standards, whereas auditors without such expertise prefer bright-line standards. On the one hand, rules make the standards more complex and difficult to apply, which potentially 
shields firms from being investigated. Consequently, managers can defend rules-based violations as innocent misstatements due to the complex nature in the standards. Donelson et al. (2012) find that restatements that are associated with rules-based standards are less likely to result in a litigation. On the other hand, auditors may "check boxes" without looking into the economic substance of transactions and, thus, are more likely to misstate financial information. However, in an international study by Henderson and O'Brien (2017), they find that the financial reporting outcome is relatively insensitive to either applying a principle or bright-line standard regarding the use of capital lease treatment among four countries: Australia, Canada, the UK, and the US. Overall, the impact of principles- (or rules-) based standards on restatements is inconclusive. I, therefore, propose the following hypothesis without predicted sign (stated in the null form).

\section{H2: There is no association between firms applying more principles-based}

\section{standards and accounting misstatements.}

Despite the extant literature that explores earnings attributes influenced by characteristics in accounting standards, there are also extensive studies that suggest timely loss recognition (TLR) to serve as an important factor to earnings quality. For example, TLR is associated with favorable outcomes such as reduced borrowing costs and superior capital investment decisions (Zhang 2008; Francis and Martin 2009). Barth et al (2008) find that firms that use IAS have less earnings management, more timely loss recognition and more value relevance of earnings. Folsom et al. (2017) document that firms using more principles-based standards are associated with more earnings informativeness, persistence, and better the predictability of future cash flows. Nevertheless, the influence of rules-based or principles-based standards on asymmetric timeliness remains unclear. I expect firms 
using more principles-based standards likely to recognize loss in accounting earnings on a more timely basis. This is because principles-based standards likely to recognize the economic substance of transactions and therefore are more likely to recognize economic loss in accounting earnings on a more timely basis. This leads to my third hypothesis (stated in the alternative form):

\section{H3: Firms applying more principles-based standards report negative earnings surprises in a more timely manner.}

\section{RESEARCH DESIGN AND SAMPLE SELECTION IV.1 Rules-Based Continuum $(R B C)$ Measure}

To quantify rules-based characteristics in accounting standards, I employ the $R B C$ measure by Mergenthaler (2011). Specifically, the measure uses four distinct indicators refined from authoritative sources in the U.S. standards-setting process, mostly the FASB (2002) and the SEC (2003), to catch the extent to which each accounting standard contains rules-based characteristic. These indicators are: (1) bright-line thresholds (BRIGHT), (2) scope and legacy exceptions (SCOPE), ${ }^{9}$ (3) large volumes of implementation guidance (GUIDE), and (4) a high level of detail (DETAIL).${ }^{10}$ All four indicators are dichotomous, denoting the presence or absence of its respective characteristic. The sum of four indicators comes to an $R B C_{1}$ score that ranges from 0 to 4 , denoting standards from the most principles-based to most rules-based standard.

\footnotetext{
${ }^{9}$ A list of relevant keywords is identified to present the indicators among accounting standards in Appendix B.

${ }^{10}$ See Appendix B for a detailed discussion of each indicator.
} 
Further, to standardize each standard relative to all other standards, $R B C_{2}$ is then proposed to factor in the mean and variance adjusted composite, using the following equation:

$$
R B C 2_{j t}=\sum_{i=1}^{4} \frac{\text { Value }_{i j t}-\overline{\text { Value }_{i}}}{\text { VIalue }_{i}}
$$

where the indicator $i$ for standard $j$ in year $t\left(\right.$ Value $\left._{i j t}\right)$ is adjusted for the mean $\left(\overline{\text { Value }_{l}}\right)$ and variance of indicator $i$ in all standards $\left(\sigma\right.$ Value $\left._{i}\right) . R B C_{2}$ is the sum of all four mean-andvariance-adjusted indicators for each standard in year $t . R B C_{2}$ puts more weight to the extreme values and it measures to what extent one particular rules-based characteristic in a standard is relative to all other standards. Thus, higher $R B C_{2}$ score identifies more extreme rules-based characteristics in standards.

\section{IV.2 Principles-Based Score (PSCORE) Measure}

\section{IV.2.1 Identifying the Keyword List}

To examine how and to what extent firms rely on principles-based standards, I adopt the PSCORE measure following Folsom et al. (2017). Despite the fact that U.S. GAAP applies to all public and private companies as well as the not-for-profit organizations, not every accounting standard is necessarily affecting each firm equally. A firm's adoption of applicable standards depends on the nature of the business and various transactions involved, whereas the relevant impact of standards' implementation depends on management's competence and intention. 
First, to determine what standards each firm is complying with, I construct a list of keywords for each ASC topic. ${ }^{11}$ I obtain and continue to use the keywords previously identified by Folsom et al. (2017) only if the ASC topics can be related to the FASB pronouncements prior to $2009 .{ }^{12}$ For those cannot be successfully located back to the FASB pronouncements, I adopt two most commonly used automatic keyword extraction methods in text mining, TextRank and RAKE, to extract keywords and phrases among the new Codification system (Mihalcea and Tarau 2004, Rose et al 2010). ${ }^{13}$ For example, ASC 820, previously FAS 157 (first effective in 2007), prescribes Fair Value Measurements. Using RAKE method, the first two sequences of words the algorithm provides are "reporting entity measures fair value using another valuation technique" and "fair value measurement shall reflect market participants expectations". I then identify (1) "fair value" within five words (preceding or following) of "measur*", ${ }^{14}(2)$ "market participants" within five words of "expectations", and (3) "valuation technique" as keywords for this standard. With a deeper look into ASC 820 I add another keyword, "observable input*". Next, to validate keywords identified can appropriately locate to the unique accounting standard, I search the keywords in the Codification system to make sure ASC 820 is returned as the first result.

After compiling the keyword list, I then search for the appearance of these keywords within entities' 10-K filings. For instance, ASC 230 (previously SFAS 95)

\footnotetext{
${ }^{11}$ Appendix C provides a list of detailed keywords identified in each ASC topic.

12 The Codification system provides interactive means to map topics from pre-codification period.

${ }^{13}$ Keywords used in Folsom et al. (2017) were identified from the FASB pronouncements up to 2006.

14 The keywords ending with * represent stemming or root words. Variation forms are also captured by textual algorithms. For example, the search for keyword "measur*" will return variations such as "measuring", "measure", and "measurement".
} 
governs Statement of Cash Flows. Keywords identified for this standard are (1) “operating", “investing”, or "financing" "activities", (2) “cash" "receipts” or "payments", and (3) "direct" or "indirect" "method". I assume every time these keywords appear in entities' annual reports, Topic 230 is referenced. I also search the commonly used titles of this standard such as "SFAS 95", "FASB Statement No. 95", ASC 230, and Topic 230. Moreover, through a closer inspection of firms' 10 -K filings, I notice firms often cite the amendments to accountings standards, now known as the Accounting Standards Update (ASU). Therefore, keywords for the amendments to ASC 230 such as "ASU 2010-08", “ASU 2012-05", and “ASU 2014-08” are considered and searched as well.

\section{IV.2.2 Relative Importance (REL_IMP) Measure}

Then, I sum up the total number of times the keywords are mentioned in a firm's annual report. To analyze cross-sectional variation of firms' reliance on principles-based standards, I standardize the raw keyword counts by adjusting for mean and variance composite following Folsom et al. (2017). This process considers the relative importance of the individual standard among all firms, where the relative importance is calculated as follows:

$$
R E L_{-} I M P_{i t s}=\frac{\text { firm_count }_{\text {its }}-\overline{\text { flrm_count }_{t s}}}{\sigma \text { firm_count }_{t s}}
$$

where I first calculate the raw keyword count of firm $i$ for standard $s$ in year $t$. Then, I adjust for the average number of times all other firms mention the keywords for standard $s$ in year $t\left(\overline{\text { frm_count }_{t s}}\right)$ and variance in all firms for standard $s$ in year $t\left(\sigma\right.$ firm_count $\left._{t s}\right)$. To avoid negative or zero weights from this standardization process, the minimum 
standardized score is added to back to $R E L \_I M P$ measure for standard $s$ in year $t$ so that it captures cross-sectional variation of firms' reliance on principles-based standards. For example, if firm $i$ doesn't mention standard $s$ in year $t$, it will receive the most negative weigh in relative importance measure as comparing to others mention standard $s$ at least once. By adding back its score, firm $i$ eventually becomes zero, which indeed receives minimum impact by standard $s$ in year $t$.

\section{IV.2.3 Firm-Level PSCORE Measure}

Following Folsom et al. (2017), I then map $R E L \_I M P$ score to $R B C_{1}$ measure to construct firm-level instrument, PSCORE. It measures the extent to which a firm's annual 10-K filing contains principles-based characteristics and the influence of each standard on the firm. Specifically, PSCORE is the product of relative importance score of firm $i$ for standard $s$ in year $t$ and the standard $s^{\prime}$ corresponding $R B C_{l}$ score in year $t$. The equation of the total PSCORE is as follows:

$$
P S C O R E_{i t}=(-1) \times \sum_{S=1}^{S}\left(R E L_{-} I M P_{i t s} \times R B C_{1 t s}\right)
$$

multiplying by -1, PSCORE increases from firms reporting more rules-based standards to firms most relying on principles-based standards (PSCORE score, the non-positive number, closest to 0). Firms applying more principles-based accounting standards report higher PSCORE values. Otherwise, lower (higher) PSCORE indicates more reliance on the rules-based (principles-based) standards. 


\section{IV.3 Research Models and Key Variables}

To test my first hypothesis that examines the influence of principles-based vs rulesbased standards on the auditors assessed level of inputs during the audit process, I regress firm $i$ 's audit fees on the firm-specific PSCORE in year $t$ and control for variables following prior literature. The OLS model is as follows:

$$
\begin{aligned}
L_{n A F_{i t}=} & \beta_{0}+\beta_{1} \text { PSCORE }_{i t}+\beta_{2} \text { BIG }_{-} 4_{i t}+\beta_{3} L N T A_{i t}+\beta_{4} L E V_{i t}+\beta_{5} L O S S_{i t}+\beta_{6} R O A_{i t} \\
& +\beta_{7} \text { GEOSEG } \\
i t & +\beta_{8} B U S S E G_{i t}+\text { Industry/Year FE }+\varepsilon_{i t}
\end{aligned}
$$

The dependent variables $L n A F_{i t}$ is the nature logarithm of firm $i$ 's audit fees in year t. A positive coefficient on $\beta_{1}$ indicates firms relying more on the principles-based standards pay greater audit fees. Otherwise, negative $\beta_{1}$ means firms applying more rulesbased standards pay more audit fees. Prior research shows that audit quality is associated with company characteristics such as company size, financial performance, and stress. Therefore, I control for the natural logarithm of total assets $\left(L N T A_{i t}\right)$, leverage $\left(L E V_{i t}\right)$, a dummy for reporting losses $\left(L O S S_{i t}\right)$, return on assets $\left(R O A_{i t}\right)$, the number of geographic and business segments $\left(G E O S E G_{i t}\right.$ and $\left.B U S S E G_{i t}\right)$. I also control for auditor size $\left(B I G_{-} 4_{i t}\right)$, following Seetharaman et al. (2002), Choi et al. (2009), and Dao et al. (2012). Industry/ year fixed effects are also considered for correlation across the time and industries.

To test my next hypothesis regarding the likelihood of reporting accounting misstatements under different standards characteristics, I regress the restatement dummy on the firm-specific PSCORE in year $t$ and other control variables. The logistic model is as follows: 


$$
\begin{aligned}
\text { Restate }_{i t}= & \beta_{0}+\beta_{1} \text { PSCORE }_{i t}+\beta_{2} \text { BIG }_{-} N_{i t}+\beta_{3} \text { BIG }_{-} 4_{i t} * \text { PSCORE }_{i t}+\beta_{4} \text { LNTA }_{i t} \\
& +\beta_{5} \text { LEV }_{i t}+\beta_{6} \text { LOSS }_{i t}+\beta_{7} \text { ROA }_{i t}+\beta_{8} \text { GEOSEG }_{i t}+\beta_{9} \text { BUSSEG }_{i t}+ \\
& \text { Industry/Year FE }+\varepsilon_{i t}
\end{aligned}
$$

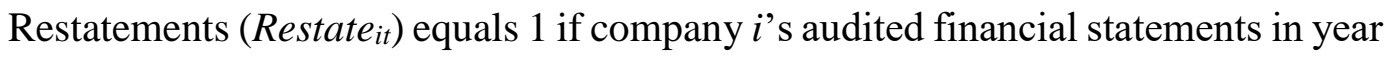
$t$ are subsequently restated, and 0 otherwise. Suggested by prior literature that auditor characteristics play influential role on the audit outcome (Francis et al. 2005, Numan and Wilekens 2012, Fung et al. 2012), I include variables to control for auditor characteristics such as auditor size $\left(B I G_{-} 4_{i t}\right)$. The interaction terms of $B I G_{-} 4_{i t} * P S C O R E_{i t}$ captures the potential incremental effect of auditor size if any on the likelihood of reporting accounting misstatements under principles-based versus rules-based standards. A positive coefficient of $\beta_{1}$ suggests firms report more accounting misstatements when relying more on principles-based accounting standard. A negative coefficient of interaction $\beta_{3}$ shows firms applying more principles-based standards with Big 4 auditors are less likely to report accounting misstatements. $L N T A_{i t}$ is employed to measure client size. Various variables, $L E V_{i t}, L_{O S S}, R_{i t}, A_{i t}, G E O S E G_{i t}$, and $B U S S E G_{i t}$, are controlled for financial stress and client complexity. Following prior research, I also control for industry/ year fixed effects in this test.

The last hypothesis investigates the asymmetric timeliness in loss recognition under the influence of rules-based or principles-based standards. I employ most frequently used measure of timely loss recognition, the reverse earnings-returns regression from Basu (1997):

$$
\begin{aligned}
E_{i, t}=\beta_{0} & +\beta_{1} D_{i t}+\beta_{2} \operatorname{Ret}_{i t}+\beta_{3} \text { PSCORE }_{i t}+\beta_{4} D_{i t} * \operatorname{Ret}_{i t}+\beta_{5} \operatorname{Ret}_{i t} * \text { PSCORE }_{i t} \\
& +\beta_{6} D_{i t} * \operatorname{Ret}_{i t} * \operatorname{PSCORE}_{i t}+\varepsilon_{i t}
\end{aligned}
$$


The "bad" news represented by losses should be reflected into returns quicker than the "good" news in an efficient market, where dummy variable $D_{i t}$ equals 1 if firm reports a loss $\left(\right.$ Ret $\left._{i t}<0\right)$. A higher $\beta_{4}$ implies more timely recognition of the incurred losses in earnings. Interacted with PSCORE, the variable of interest in this test is $D_{i t} * \operatorname{Ret}_{i t} *$ PSCORE $_{i t}$ which captures the incremental influence of principles-based standards on firms' reporting quality. I expect the coefficient on the interaction term $\beta_{6}$ to be positive that firms applying more principles-based standards will report 'bad news' more quickly than 'good news', where prior literature suggests that accounting quality could be improved by eliminating alternative accounting methods that are less reflective of firms' economic performance.

\section{IV.4 Sample Selection}

The Accounting Standards Codification is the current single source of U.S. GAAP. I obtain the Codification via the FASB Accounting Standards Codification website (asc.fasb.org). Following Mergenthaler (2011), I also obtain authoritative standards prior to 2009, including Accounting Research Bulletins (ARBs), Accounting Principles Board opinions (APBs), Statements of Financial Accounting Standards (SFAS), Statement of Financial Accounting Concepts (SFAC) and the SEC Staff Accounting Bulletin (SAB) $101 .{ }^{15}$

The sample period begins in 2009. I use 2009 as the base year to construct $R B C$ score where I can locate U.S. accounting standards in the form of "FASB Pronouncements"

\footnotetext{
${ }^{15}$ The Codification system is effective in the first interim and annual periods ending after September 15, 2009.
} 
to ASC system. I then update the amendments issued in the form of Accounting Standards Updates from FASB's website to their corresponding ASC topics every year from 20092014, with the average of 16 updates a year. My sample period ends in 2014 but I extend the restated period until 2016 to factor in the time lag between the occurrences of financial misstatements and subsequent financial restatements.

Panel A of Table 1 presents the sample selection criteria. Initially, I obtained 62,291 annual reports between 2009 and 2014 from the SEC Edgar database. Due to the excessive volume of $10-\mathrm{K}$ filings, I decide to only include the $\mathrm{S} \& \mathrm{P} 500$ companies in my current research. ${ }^{16}$ After excluding financial institutions, I then apply textual analysis technique to remove irrelevant information in each annual report such as html tags and corrupted/unreadable characters. This leaves me with 2,263 annual reports from 394 distinct companies. I obtain financial data from COMPUSTAT and audit information such as auditors, audit fees, and restatements from AuditAnalytic. I deleted 853 firm-year observations without audit and financial data and winsorized ROA and LEV at the 1 and 99 percent levels. I also require firms to report consecutive six years' 10-K filings. My primary sample consists of 1,410 firm-year observations among 235 S\&P 500 companies. The return data is collected from CRSP. After deleting missing return data, the sample for the timely loss recognition test has 228 firms with 1,322 firm year observations. Panel B describes the number of S\&P 500 firms by 2-digit SIC industry codes. While "Business Services" and "Electric, Gas, \& Sanitary Services" are the two industries that have the most

\footnotetext{
${ }^{16}$ The original download from Edgar database includes 62,291 of 10-K filings from 2009 to 2014, exceeding 555 GB.
} 
numbers of S\&P 500 firms (27 and 24 companies, relatively), over $80 \%$ of the industries have less than 10 companies.

\section{EMPIRICAL RESULTS}

\section{V.1 Descriptive Statistics}

First, to validate my $R B C_{1}$ measure under the Codification system, I compare my $R B C_{1}$ scores in 2009 with scores used in Mergenthaler (2011). Untabulated analysis reveals that, among 78 out of 96 ASC Topics successfully located to FASB pronouncements, sixtysix are perfectly matched with Mergenthaler (2011) scores, while the rest are slightly different (9 out of 11 are due to word count indicator calculation). Table 2 lists the $R B C_{1}$ scores for major ASC Topics between 2009 and 2014. Consistent with Donelson et al (2016), I find “ASC 330 Inventory”, “ASC 420 Exit or Disposal Cost Obligations”, “ASC 835 Interest" are ranked as most principles-based standards. Accounting for "Intangibles Goodwill and Other" (ASC 350), "Income Taxes" (ASC 740), "Consolidation” (Topic 810), "Leases" (ASC 840) are the most rules-oriented. Over the years, $R B C_{1}$ scores seem to stay relatively sticky except for the rise in 2014 as shown in Figure 1. The increase confirms the concern that existing or newly added standards now contain more rules-based characteristics with the Accounting Standard Updates. Table 3 shows the list of $R B C_{2}$ scores that includes the mean and variance adjusted composite of $R B C_{1}$. Figure 2 shows that different from the trend of $R B C_{1}, R B C_{2}$ continues to decline until 2013, indicating that U.S. GAAP became less rules-based before 2013, although $R B C_{2}$ increases significantly in 2014. Consistent with Figure 1, existing or newly added standards now contain more rulesbased characteristics with the ASUs. 
Panel A of Table 4 summarizes the descriptive information on the variables. Ninety-nine percent of the firms employ Big 4 auditors. Also, the auditor turnover is very low that only five firms switch from one Big 4 to another. Since I focus on S\&P 500 companies, the firms are relatively large (LNTA), more complex (GEOSEG and BUSSEG), and have less financial stress $(L E V, R O A$, and $L O S S)$. Panel B presents a correlation matrix for variables in the audit fee and restatement models. Nature logarithm of audit fees (LNAF) and PSCORE have a Pearson correlation of -0.34 (Spearman -0.40) while PSCORE isn't correlated with restatements in the test. In addition, as expected, audit fees are most strongly correlated with firm size (Pearson 0.77, Spearman 0.76). Panel C describes the average PSCORE based on the 2-digit SIC industry portfolios. It is essential to understand the impact of accounting standards applicable to different industries. Among 43 industries in total, "Electric, Gas, \& Sanitary Services" seems to be the most rules-oriented during the sample period industry (Mean PSCORE $=-86.50$ ), while "Transportation Services" industry applies the most principles-based standards (Mean PSCORE $=-20.03$ ). Industries like "Nonmetallic Minerals, Except Fuels", "Industrial Machinery \& Equipment", "Furniture \& Homefurnishings Stores", and "Metal, Mining" are also using more rulesbased standards comparing to industries such as "Building Materials \& Gardening Supplies", "Automative Dealers \& Service Stations", "General Merchandise Stores", and "Water Transportation" are complying with more principles- based standards.

Next, the time trend for PSCORE is shown in Figure 3. Overall, there does not appear to be a clear trend over time. PSCORE dropped since 2009, indicating firms were complying with less principles-based standards. Later, it holds relatively stable from 2011 to 2013 with a slightly increase in 2014. Such increase in PSCORE suggests that firms are 
actually applying more principles-based standards despite the fact that $R B C_{1}$ has increased to more rules-based in 2014 as mentioned in Figure 1. Figure 4A displays the PSCORE among Big 4 audit firms over the sample period. Taken together with the finding in Figure 4B, it appears that companies having KPMG or Ernst \& Young rely more on the principlesbased standards and they pay less audit fees, while Deloitte and PricewaterhouseCoopers have clients applying less principles-based standards and they charge higher audit fees.

\section{V.2 Regression analyses}

Table 5 reports the regression results for audit fee model. The coefficient of PSCORE is negative and significant, meaning PSCORE is negatively associated with the audit fees (coefficient $=-0.001, t=-1.98$ ). This result is consistent with the finding in Big 4 audit firms that suggests firms applying more principles-based accounting standards tend to pay less audit fees. Firm complexity (GEOSEG, BUSSEG) and size (LNTA) are all positively associated with audit fees. ${ }^{17}$ Higher audit fees mean that auditors assess higher audit risk when clients relying more rules-based standards where management can manipulate earnings through transaction structuring. In other words, because firms applying more principles-based standards need to exercise more professional judgment and greater expertise their financial information tend to represent the underlying economic substance of transactions. Such firms report higher accounting quality and are assessed at lower audit risk. The net effect shows that firms applying more principles-based accounting standards are charged with less audit fees. In fact, this result is consistent with the findings

\footnotetext{
${ }^{17}$ In untabulated analysis, my results are robust if using audit specialists (measured as auditors' market share at 2-digis SIC) to proxy auditor characteristics.
} 
from prior experimental studies where CFO are less likely to report aggressively and auditors are more likely to constrain aggressive reporting under principles-based accounting standards (Agoglia et al 2011, Cohen et al 2013).

Results for the restatement model are presented in Table 6. PSCORE is negative but insignificant associated with restatements. Coefficients of Big 4 and return on assets are positive but insignificant and all other variables are negative and insignificant at any conventional levels. The results show that PSCORE is not associated with the likelihood of reporting accounting misstatements, suggesting that whether firms applying rules- or principles-based standards do not affect the audit outcome. This result needs to be interpreted with care because the likelihood of misstatements should be fewer for S\&P 500 companies. In fact, only $29.8 \%$ of these firms restate their financial statements during $2009-2014 .{ }^{18}$

Overall, I find evidence that PSCORE is negatively associated with the audit fees but not related to restatements, suggesting that auditors do consider assessed level of inputs, the precision, and complexity of relevant standards but the nature of accounting standards doesn't affect the outcome of audit process.

Next, I measure earnings quality by timely loss recognition. Panel A of Tables 7 presents the descriptive information about the variables in the model and Panel B reports the correlation matrix. The interaction of $D *$ Ret has negative correlations of -0.08 with earnings while the interaction of $R * P S C O R E$ and $D * R * P S C O R E$ are both positively correlated with earnings (Spearman $=0.14$ and 0.08 , respectively).

\footnotetext{
${ }^{18}$ In the sample of S\&P 500 companies, 70 out of 235 firms reported 116 restatements during 2009-2014.
} 
Table 8 shows that PSCORE is positively associated with earnings at the $5 \%$ level (coefficient $=0.000, t=2.12$ ). The incremental coefficient on negative returns, $D * \operatorname{Ret}$, is 0.11 and statistically significant at the $5 \%$ level, indicating that on average sample firms report losses in a more timely fashion than gains. The total timeliness coefficient is 0.077 (the sum of 0.11 and -0.033). The interaction of return and PSCORE is negative and significant at the $1 \%$ level (coefficient $=-0.001, t=-3.37$ ). However, the variable of interest, the interaction of negative returns and PSCORE is positive but not statistically significant at any conventional levels.

Overall, the results indicate that PSCORE doesn't impact on timeliness in loss recognition, indicating that timely loss recognition (TLR) is insensitive with firms' choice of applying more principles- (or rules-) based accounting standards.

\section{CONCLUSIONS, CONTRIBUTIONS, AND LIMITATIONS}

This study examines the effects of the nature of accounting standards on audit quality and earnings attributes. Specifically, whether firms' reliance on more principles(or rules-) based standards are associated with higher audit fees, the incidence of accounting misstatements, and more timely loss recognition. I employ the $R B C$ measure following Mergenthaler (2011) to capture rules-oriented features contained in each FASB ASC topics. Next, using keyword extraction approach developed by Folsom et al. (2017), I construct the firm-level instrument, PSCORE, to map the $R B C$ scores to firms' annual reports. I find that auditors consider the precision and complexity in accounting standards when assessing the level of audit inputs, but the nature of accounting standards doesn't affect the outcome of audit process. In addition, the timeliness in loss recognition is 
insensitive to firms' choice of applying more principles- (or rules-) based accounting standards. Overall, the empirical results suggest that the optimal blend of accounting standards must necessarily contain both principles-based and rules-based characteristics.

This study contributes to the extant literature in several ways. First, this is the first study to provide direct empirical evidence on the association between the nature of accounting standards and audit quality. Prior research provides extensive indirect evidence, mostly in lease classification experimental settings, to evaluate the effects of principlesbased versus rules-based characteristics on audit quality such as jury verdicts against auditors, the strength of audit committee, and the strength of financial regulatory regime (Agoglia et al. 2011, Kadous and Mercer 2012, Cohen et al. 2013). Second, prior studies (e.g. Mergenthaler 2011, Folsom et al. 2017) provide evidence on the effects of principlesbased versus rules-based characteristics on properties of earnings. This paper complements this steam of earnings quality literature by examining asymmetric timeliness in loss recognition. Third, this is the first study to empirically identify rules-based characteristics in U.S. GAAP under the FASB ASC topical categories. Finally, this paper also contributes greatly to the continuous debate over whether to implement principles-oriented reporting system even after the convergence process. The results of this study should be of interest to preparers, auditors, U.S. standards setters, and accounting researchers.

This dissertation has several limitations. First, due to the excessive volume in companies' 10-k filings my dissertation emphasizes on S\&P 500 firms and the sample period ends in 2014. In future extensions, it is worthwhile to investigate all U.S. companies with more recent changes in accounting standards (e.g. lease classification, revenue recognition). Second, both macro-level $R B C$ score and firm-level PSCORE measure are 
relatively new instruments that may need further refinement. $R B C$ measure may not capture all possible characterizations in principles and rules. Finally, although this dissertation provides evidence that contributes to the debate over how principles- and rules-based standards impact the audit process and financial reporting, I draw no conclusion on the precedence of principles- based standards over rules-based standards. 
TABLE 1

Sample Selection

\begin{tabular}{lcc}
\hline Panel A: Number of Observations & & \\
\hline & $\begin{array}{c}\text { Firm } \\
\text { Observations }\end{array}$ & $\begin{array}{c}\text { Firm-Year } \\
\text { Observations }\end{array}$ \\
Annual reports between 2009 and 2014: & 10,580 & 62,291 \\
$\quad$ Less: Firms are not S\&P 500 & $\underline{(10,148)}$ & $\underline{(59,892)}$ \\
Subtotal & $\underline{(38)}$ & $\underline{(136)}$ \\
$\quad$ Less: Firms are financial institutions (SIC 6000) & 394 & 2,263 \\
Subtotal & $(159)$ & $(853)$ \\
$\quad$ Less: Firms with missing variables; LEV and ROA & $\mathbf{2 3 5}$ & $\mathbf{1 , 4 1 0}$ \\
winsorized at 1\% and 99\%. & $\underline{(7)}$ & $\underline{\mathbf{( 8 8 )}}$ \\
Primary Analysis Sample & $\mathbf{2 2 8}$ & $\mathbf{1 , 3 2 2}$ \\
$\quad$ Less: Firms missing return data & & \\
Loss Recognition Sample &
\end{tabular}

Data Source: Compustat, CRSP, and AuditAnalytics. 
TABLE 1

Sample Selection

(Continued)

\begin{tabular}{|c|c|c|c|c|c|}
\hline \multicolumn{6}{|c|}{ Panel B: Number of S\&P 500 Firms by 2-digit SIC Industries } \\
\hline 10 & Metal, Mining & 1 & 44 & Water Transportation & 1 \\
\hline 13 & Oil \& Gas Extraction & 10 & 45 & Transportation by Air & 5 \\
\hline 14 & Nonmetallic Minerals, Except Fuels & 1 & 47 & Transportation Services & 2 \\
\hline 15 & General Building Contractors & 2 & 48 & Communications & 6 \\
\hline 16 & Heavy Construction, Except Building & 1 & 49 & Electric, Gas, \& Sanitary Services & 24 \\
\hline 20 & Food \& Kindred Products & 15 & 50 & Wholesale Trade - Durable Goods & 4 \\
\hline 21 & Tobacco Products & 2 & 51 & Wholesale Trade - Nondurable Goods & 3 \\
\hline 22 & Textile Mill Products & 1 & 52 & Building Materials \& Gardening Supplies & 5 \\
\hline 23 & Apparel \& Other Textile Products & 4 & 53 & General Merchandise Stores & 7 \\
\hline 25 & Furniture \& Fixtures & 1 & 54 & Food Stores & 1 \\
\hline 26 & Paper \& Allied Products & 2 & 55 & Automative Dealers \& Service Stations & 3 \\
\hline 28 & Chemical \& Allied Products & 18 & 56 & Apparel \& Accessory Stores & 7 \\
\hline 29 & Petroleum \& Coal Products & 4 & 57 & Furniture \& Homefurnishings Stores & 1 \\
\hline 30 & Rubber \& Miscellaneous Plastics Products & 2 & 58 & Eating \& Drinking Places & 4 \\
\hline 31 & Leather \& Leather Products & 1 & 59 & Miscellaneous Retail & 5 \\
\hline 34 & Fabricated Metal Products & 3 & 67 & Holding \& Other Investment Offices & 1 \\
\hline 35 & Industrial Machinery \& Equipment & 11 & 72 & Personal Services & 1 \\
\hline 36 & Electronic \& Other Electric Equipment & 14 & 73 & Business Services & 27 \\
\hline 37 & Transportation Equipment & 7 & 78 & Motion Pictures & 1 \\
\hline 38 & Instruments \& Related Products & 19 & 80 & Health Services & 2 \\
\hline 40 & Railroad Transportation & 3 & 87 & Engineering \& Management Services & 2 \\
\hline 42 & Trucking \& Warehousing & 1 & & Total & 235 \\
\hline
\end{tabular}


TABLE 2

List of $R B C_{1}$ Scores from 2009 to 2014

\begin{tabular}{|c|c|c|c|c|c|c|c|}
\hline ASC \# & ASC Topic & 2009 & 2010 & 2011 & 2012 & 2013 & 2014 \\
\hline 105 & Generally Accepted Accounting Principles & 0 & 0 & 0 & 0 & 0 & 0 \\
\hline 205 & Presentation of Financial Statements & 0 & 0 & 0 & 0 & 0 & 1 \\
\hline 210 & Balance Sheet & 0 & 0 & 0 & 0 & 0 & 0 \\
\hline & Income Statement-Reporting Comprehensive & & & & & & \\
\hline 220 & Income & 1 & 1 & 1 & 1 & 1 & 1 \\
\hline 225 & Income Statement & 1 & 1 & 1 & 1 & 1 & 1 \\
\hline 230 & Statement of Cash Flows & 0 & 0 & 0 & 0 & 0 & 1 \\
\hline 235 & Notes to Financial Statements & 0 & 0 & 0 & 0 & 0 & 0 \\
\hline 250 & Accounting Changes and Error Corrections & 0 & 0 & 0 & 0 & 0 & 0 \\
\hline 255 & Changing Prices & 0 & 0 & 0 & 0 & 0 & 0 \\
\hline 260 & Earnings Per Share & 1 & 1 & 1 & 1 & 1 & 1 \\
\hline 270 & Interim Reporting & 0 & 0 & 0 & 0 & 0 & 0 \\
\hline 272 & Limited Liability Entities & 2 & 2 & 2 & 2 & 2 & 2 \\
\hline 280 & Segment Reporting & 2 & 2 & 2 & 2 & 2 & 2 \\
\hline 310 & Receivables & 0 & 0 & 0 & 0 & 0 & 0 \\
\hline 320 & Investments - Debt and Equity Securities & 2 & 2 & 2 & 2 & 2 & 2 \\
\hline 323 & Investments - Equity Method and Joint Ventures & 3 & 3 & 3 & 3 & 3 & 3 \\
\hline 330 & Inventory & 0 & 0 & 0 & 0 & 0 & 0 \\
\hline 350 & Intangibles - Goodwill and Other & 3 & 3 & 3 & 3 & 3 & 3 \\
\hline 360 & Property, Plant, and Equipment & 2 & 2 & 2 & 2 & 2 & 2 \\
\hline 405 & Liabilities & 2 & 2 & 2 & 2 & 2 & 2 \\
\hline 410 & Asset Retirement and Environmental Obligations & 1 & 1 & 1 & 1 & 1 & 1 \\
\hline 420 & Exit or Disposal Cost Obligations & 0 & 0 & 0 & 0 & 0 & 0 \\
\hline 440 & Commitments & 1 & 1 & 1 & 1 & 1 & 1 \\
\hline 450 & Contingencies & 1 & 1 & 1 & 1 & 1 & 1 \\
\hline 470 & Debt & 2 & 2 & 2 & 2 & 2 & 3 \\
\hline 480 & Distinguishing Liabilities from Equity & 1 & 1 & 1 & 1 & 1 & 1 \\
\hline
\end{tabular}


TABLE 2 (Continued)

\begin{tabular}{|c|c|c|c|c|c|c|c|}
\hline ASC \# & ASC Topic & 2009 & 2010 & 2011 & 2012 & 2013 & 2014 \\
\hline 505 & Equity & 1 & 1 & 1 & 1 & 1 & 1 \\
\hline 605 & Revenue Recognition & 2 & 2 & 2 & 2 & 2 & 2 \\
\hline 715 & Compensation - Retirement Benefits & 3 & 3 & 3 & 3 & 3 & 3 \\
\hline 718 & Compensation - Stock Compensation & 2 & 2 & 2 & 2 & 2 & 2 \\
\hline 720 & Other Expenses & 0 & 0 & 0 & 0 & 0 & 0 \\
\hline 730 & Research and Development & 1 & 1 & 1 & 1 & 1 & 1 \\
\hline 740 & Income Taxes & 3 & 3 & 3 & 3 & 3 & 3 \\
\hline 805 & Business Combinations & 2 & 2 & 2 & 2 & 2 & 2 \\
\hline 810 & Consolidation & 3 & 3 & 3 & 3 & 3 & 3 \\
\hline 815 & Derivatives and Hedging & 3 & 3 & 2 & 2 & 2 & 2 \\
\hline 820 & Fair Value Measurements & 2 & 2 & 2 & 2 & 2 & 2 \\
\hline 825 & Financial Instruments & 1 & 1 & 1 & 1 & 1 & 1 \\
\hline 830 & Foreign Currency Matters & 1 & 1 & 1 & 1 & 1 & 1 \\
\hline 835 & Interest & 0 & 0 & 0 & 0 & 0 & 0 \\
\hline 840 & Leases & 4 & 4 & 4 & 4 & 4 & 4 \\
\hline 845 & Nonmonetary Transactions & 1 & 1 & 1 & 1 & 1 & 1 \\
\hline 850 & Related Party Disclosures & 1 & 1 & 1 & 1 & 1 & 1 \\
\hline 852 & Reorganizations & 0 & 0 & 0 & 0 & 0 & 0 \\
\hline 855 & Subsequent Events & 1 & 1 & 1 & 1 & 1 & 1 \\
\hline 860 & Transfers and Servicing & 1 & 1 & 1 & 1 & 1 & 1 \\
\hline 912 & Contractors - Federal Government & 0 & 0 & 0 & 0 & 0 & 0 \\
\hline 915 & Development Stage Entities & 0 & 0 & 0 & 0 & 0 & 0 \\
\hline 920 & Entertainment - Broadcasters & 0 & 0 & 0 & 0 & 0 & 0 \\
\hline 922 & Entertainment - Cable Television & 0 & 0 & 0 & 0 & 0 & 0 \\
\hline 924 & Entertainment - Casinos & 0 & 0 & 0 & 0 & 0 & 0 \\
\hline 926 & Entertainment - Films & 0 & 0 & 0 & 0 & 0 & 0 \\
\hline 928 & Entertainment - Music & 0 & 0 & 0 & 0 & 0 & 0 \\
\hline 932 & Extractive Activities - Oil and Gas & 2 & 2 & 2 & 2 & 2 & 2 \\
\hline 944 & Financial Services - Insurance & 1 & 1 & 1 & 1 & 1 & 1 \\
\hline 946 & Financial Services - Investment Companies & 0 & 0 & 0 & 0 & 0 & 2 \\
\hline
\end{tabular}


TABLE 2 (Continued)

\begin{tabular}{|c|c|c|c|c|c|c|c|}
\hline ASC \# & ASC Topic & 2009 & 2010 & 2011 & 2012 & 2013 & 2014 \\
\hline 948 & Financial Services - Mortgage Banking & 1 & 1 & 1 & 1 & 1 & 1 \\
\hline 950 & Financial Services - Title Plant & 0 & 0 & 0 & 0 & 0 & 0 \\
\hline 952 & Franchisors & 0 & 0 & 0 & 0 & 0 & 0 \\
\hline 954 & Health Care Entities & 3 & 3 & 3 & 3 & 3 & 3 \\
\hline 958 & Not-for-Profit Entities & 1 & 1 & 1 & 1 & 1 & 1 \\
\hline 960 & $\begin{array}{l}\text { Plan Accounting - Defined Benefit Pension Plans } \\
\text { Plan Accounting - Defined Contribution Pension }\end{array}$ & 0 & 0 & 0 & 0 & 0 & 0 \\
\hline 962 & Plans & 0 & 0 & 0 & 0 & 0 & 0 \\
\hline 970 & Real Estate - General & 1 & 1 & 1 & 1 & 1 & 1 \\
\hline 976 & Real Estate - Retail Land & 3 & 3 & 3 & 3 & 3 & 3 \\
\hline 980 & Regulated Operations & 1 & 1 & 1 & 1 & 1 & 1 \\
\hline 985 & Software & 2 & 2 & 2 & 2 & 2 & 2 \\
\hline
\end{tabular}


FIGURE 1

Changes of $R B C_{1}$ in ASC Topics

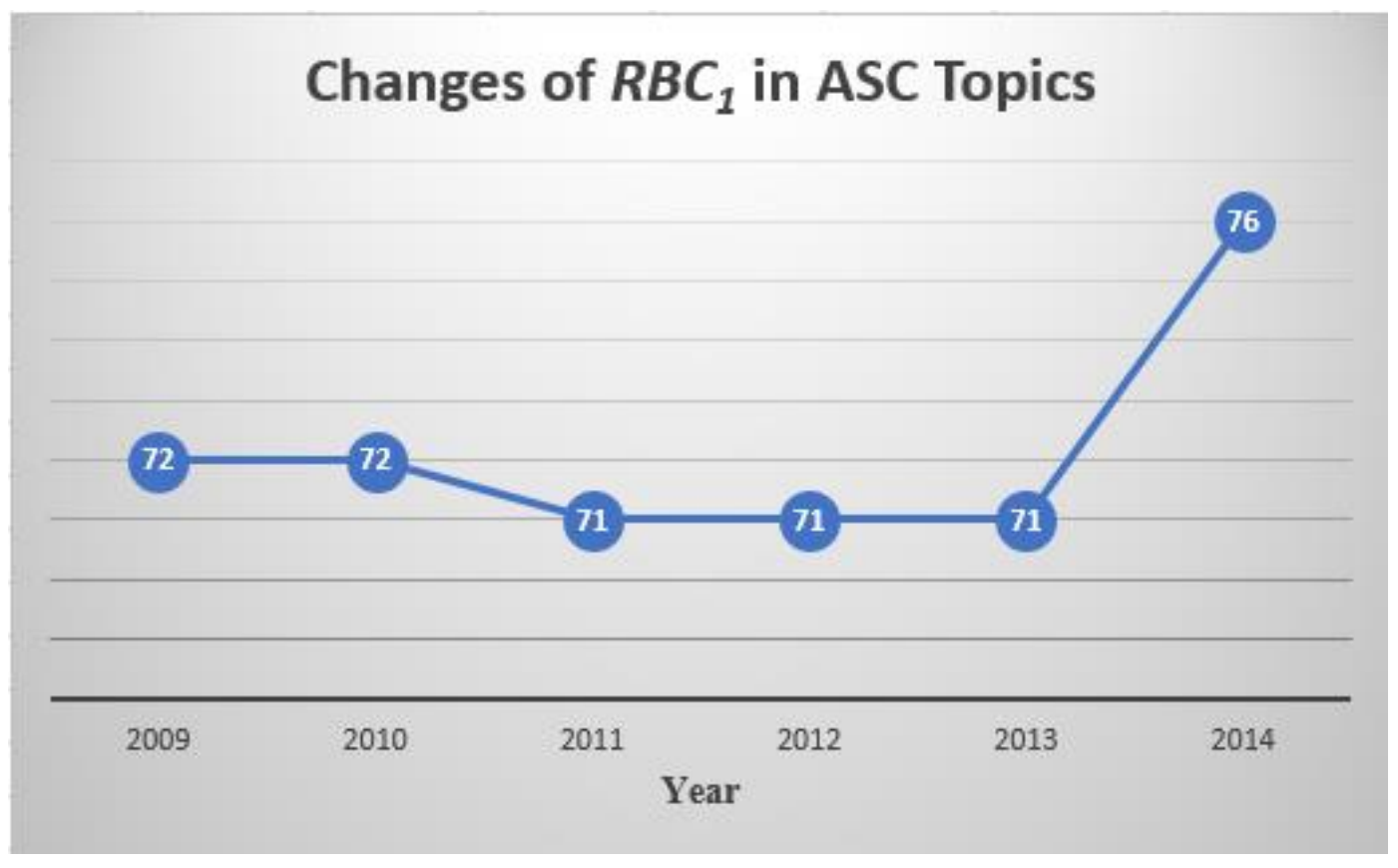

Figure 1 plots the changes of $R B C_{l}$ scores in ASC Topics between 2009-2014. 
TABLE 3

List of $R B C_{2}$ Scores from 2009 to 2014

\begin{tabular}{|c|c|c|c|c|c|c|c|}
\hline ASC \# & ASC Topics & 2009 & 2010 & 2011 & 2012 & 2013 & 2014 \\
\hline 105 & Generally Accepted Accounting Principles & -2.55 & -2.55 & -2.55 & -2.55 & -2.55 & -2.55 \\
\hline 205 & Presentation of Financial Statements & & & & & -2.55 & -0.17 \\
\hline 210 & Balance Sheet & & & -2.55 & -2.55 & -2.55 & -2.55 \\
\hline & Income Statement - Reporting Comprehensive & & & & & & \\
\hline 220 & Income & -0.54 & -0.54 & -0.54 & -0.54 & -0.54 & -0.54 \\
\hline 225 & Income Statement & -0.54 & -0.54 & -0.54 & -0.54 & -0.54 & -0.54 \\
\hline 230 & Statement of Cash Flows & -2.55 & -2.55 & -2.55 & -2.55 & -2.55 & -0.17 \\
\hline 235 & Notes to Financial Statements & -2.55 & -2.55 & -2.55 & -2.55 & -2.55 & -2.55 \\
\hline 250 & Accounting Changes and Error Corrections & -2.55 & -2.55 & -2.55 & -2.55 & -2.55 & -2.55 \\
\hline 255 & Changing Prices & -2.55 & -2.55 & -2.55 & -2.55 & -2.55 & -2.55 \\
\hline 260 & Earnings Per Share & -0.54 & -0.54 & -0.54 & -0.54 & -0.54 & -0.54 \\
\hline 270 & Interim Reporting & -2.55 & -2.55 & -2.55 & -2.55 & -2.55 & -2.55 \\
\hline 272 & Limited Liability Entities & 1.68 & 1.68 & 1.68 & 1.68 & 1.68 & 1.68 \\
\hline 280 & Segment Reporting & 1.68 & 1.68 & 1.68 & 1.68 & 1.68 & 1.68 \\
\hline 310 & Receivables & & -2.55 & -2.55 & -2.55 & -2.55 & -2.55 \\
\hline 320 & Investments - Debt and Equity Securities & 1.68 & 1.68 & 1.68 & 1.68 & 1.68 & 1.68 \\
\hline 323 & Investments - Equity Method and Joint Ventures & 5.59 & 5.59 & 5.59 & 5.59 & 5.59 & 7.97 \\
\hline 330 & Inventory & -2.55 & -2.55 & -2.55 & -2.55 & -2.55 & -2.55 \\
\hline 350 & Intangibles - Goodwill and Other & 5.75 & 5.75 & 5.75 & 5.75 & 5.75 & 5.75 \\
\hline 360 & Property, Plant, and Equipment & 1.84 & 1.84 & 1.84 & 1.84 & 1.84 & 1.84 \\
\hline 405 & Liabilities & 1.68 & 1.68 & 1.68 & 1.68 & 1.68 & 1.68 \\
\hline 410 & Asset Retirement and Environmental Obligations & -0.54 & -0.54 & -0.54 & -0.54 & -0.54 & -0.54 \\
\hline 420 & Exit or Disposal Cost Obligations & -2.55 & -2.55 & -2.55 & -2.55 & -2.55 & -2.55 \\
\hline 440 & Commitments & -0.33 & -0.33 & -0.33 & -0.33 & -0.33 & -0.33 \\
\hline 450 & Contingencies & -0.54 & -0.54 & -0.54 & -0.54 & -0.54 & -0.54 \\
\hline 470 & Debt & 1.68 & 1.68 & 1.68 & 1.68 & 1.68 & 4.06 \\
\hline 480 & Distinguishing Liabilities from Equity & -0.54 & -0.54 & -0.54 & -0.54 & -0.54 & -0.54 \\
\hline 505 & Equity & -0.33 & -0.33 & -0.33 & -0.33 & -0.33 & -0.33 \\
\hline
\end{tabular}


TABLE 3 (Continued)

\begin{tabular}{|c|c|c|c|c|c|c|c|}
\hline ASC \# & ASC Topics & 2009 & 2010 & 2011 & 2012 & 2013 & 2014 \\
\hline 605 & Revenue Recognition & 1.68 & 1.68 & 1.68 & 1.68 & 1.68 & 1.68 \\
\hline 715 & Compensation - Retirement Benefits & 4.06 & 4.06 & 4.06 & 4.06 & 4.06 & 4.06 \\
\hline 718 & Compensation - Stock Compensation & 1.84 & 1.84 & 1.84 & 1.84 & 1.84 & 1.84 \\
\hline 720 & Other Expenses & & -2.55 & -2.55 & -2.55 & -2.55 & -2.55 \\
\hline 730 & Research and Development & -0.54 & -0.54 & -0.54 & -0.54 & -0.54 & -0.54 \\
\hline 740 & Income Taxes & 4.06 & 4.06 & 4.06 & 4.06 & 4.06 & 4.06 \\
\hline 805 & Business Combinations & 1.84 & 1.84 & 1.84 & 1.84 & 1.84 & 1.84 \\
\hline 810 & Consolidation & 4.06 & 4.06 & 4.06 & 4.06 & 4.06 & 4.06 \\
\hline 815 & Derivatives and Hedging & 5.75 & 5.75 & 1.84 & 1.84 & 1.84 & 3.37 \\
\hline 820 & Fair Value Measurements & 1.84 & 1.84 & 1.84 & 1.84 & 1.84 & 1.84 \\
\hline 825 & Financial Instruments & -0.54 & -0.54 & -0.54 & -0.54 & -0.54 & -0.54 \\
\hline 830 & Foreign Currency Matters & -0.33 & -0.33 & -0.33 & -0.33 & -0.33 & -0.33 \\
\hline 835 & Interest & -2.55 & -2.55 & -2.55 & -2.55 & -2.55 & -0.17 \\
\hline 840 & Leases & 7.97 & 7.97 & 7.97 & 7.97 & 7.97 & 7.97 \\
\hline 845 & Nonmonetary Transactions & -0.54 & -0.54 & -0.54 & -0.54 & -0.54 & -0.54 \\
\hline 850 & Related Party Disclosures & -0.33 & -0.33 & -0.33 & -0.33 & -0.33 & -0.33 \\
\hline 852 & Reorganizations & -2.55 & -2.55 & -2.55 & -2.55 & -2.55 & -2.55 \\
\hline 855 & Subsequent Events & -0.54 & -0.54 & -0.54 & -0.54 & -0.54 & -0.54 \\
\hline 860 & Transfers and Servicing & -0.17 & -0.17 & -0.17 & -0.17 & -0.17 & -0.17 \\
\hline 912 & Contractors - Federal Government & -2.55 & -2.55 & -2.55 & -2.55 & -2.55 & -2.55 \\
\hline 915 & Development Stage Entities & -2.55 & -2.55 & -2.55 & -2.55 & -2.55 & -2.55 \\
\hline 920 & Entertainment - Broadcasters & -2.55 & -2.55 & -2.55 & -2.55 & -2.55 & -2.55 \\
\hline 922 & Entertainment - Cable Television & -2.55 & -2.55 & -2.55 & -2.55 & -2.55 & -2.55 \\
\hline 924 & Entertainment - Casinos & & -2.55 & -2.55 & -2.55 & -2.55 & -2.55 \\
\hline 926 & Entertainment - Films & & & & -2.55 & -2.55 & -2.55 \\
\hline 928 & Entertainment - Music & -2.55 & -2.55 & -2.55 & -2.55 & -2.55 & -2.55 \\
\hline 932 & Extractive Activities - Oil and Gas & 1.68 & 1.68 & 1.68 & 1.68 & 1.68 & 1.68 \\
\hline 944 & Financial Services - Insurance & -0.54 & -0.54 & -0.54 & -0.54 & -0.54 & -0.54 \\
\hline
\end{tabular}




\begin{tabular}{|c|c|c|c|c|c|c|c|}
\hline \multicolumn{8}{|c|}{ TABLE 3 (Continued) } \\
\hline ASC \# & ASC Topics & 2009 & 2010 & 2011 & 2012 & 2013 & 2014 \\
\hline 946 & Financial Services - Investment Companies & & & & & & 1.68 \\
\hline 948 & Financial Services - Mortgage Banking & -0.54 & -0.54 & -0.54 & -0.54 & -0.54 & -0.54 \\
\hline 950 & Financial Services - Title Plant & -2.55 & -2.55 & -2.55 & -2.55 & -2.55 & -2.55 \\
\hline 952 & Franchisors & -2.55 & -2.55 & -2.55 & -2.55 & -2.55 & -2.55 \\
\hline 954 & Health Care Entities & 4.06 & 4.06 & 4.06 & 4.06 & 4.06 & 4.06 \\
\hline 958 & Not-for-Profit Entities & -0.54 & -0.54 & -0.54 & -0.54 & -0.54 & -0.54 \\
\hline 960 & $\begin{array}{l}\text { Plan Accounting - Defined Benefit Pension Plans } \\
\text { Plan Accounting - Defined Contribution Pension }\end{array}$ & -2.55 & -2.55 & -2.55 & -2.55 & -2.55 & -2.55 \\
\hline 962 & Plans & -2.55 & -2.55 & -2.55 & -2.55 & -2.55 & -2.55 \\
\hline 970 & Real Estate - General & -0.54 & -0.54 & -0.54 & -0.54 & -0.54 & -0.54 \\
\hline 976 & Real Estate - Retail Land & 5.96 & 5.96 & 5.96 & 5.96 & 5.96 & 5.96 \\
\hline 980 & Regulated Operations & -0.54 & -0.54 & -0.54 & -0.54 & -0.54 & -0.54 \\
\hline 985 & Software & 1.84 & 1.84 & 1.84 & 1.84 & 1.84 & 1.84 \\
\hline
\end{tabular}


FIGURE 2

Changes of $R B C_{2}$ in ASC Topics

\section{Changes of RBC2 in ASC Topics}

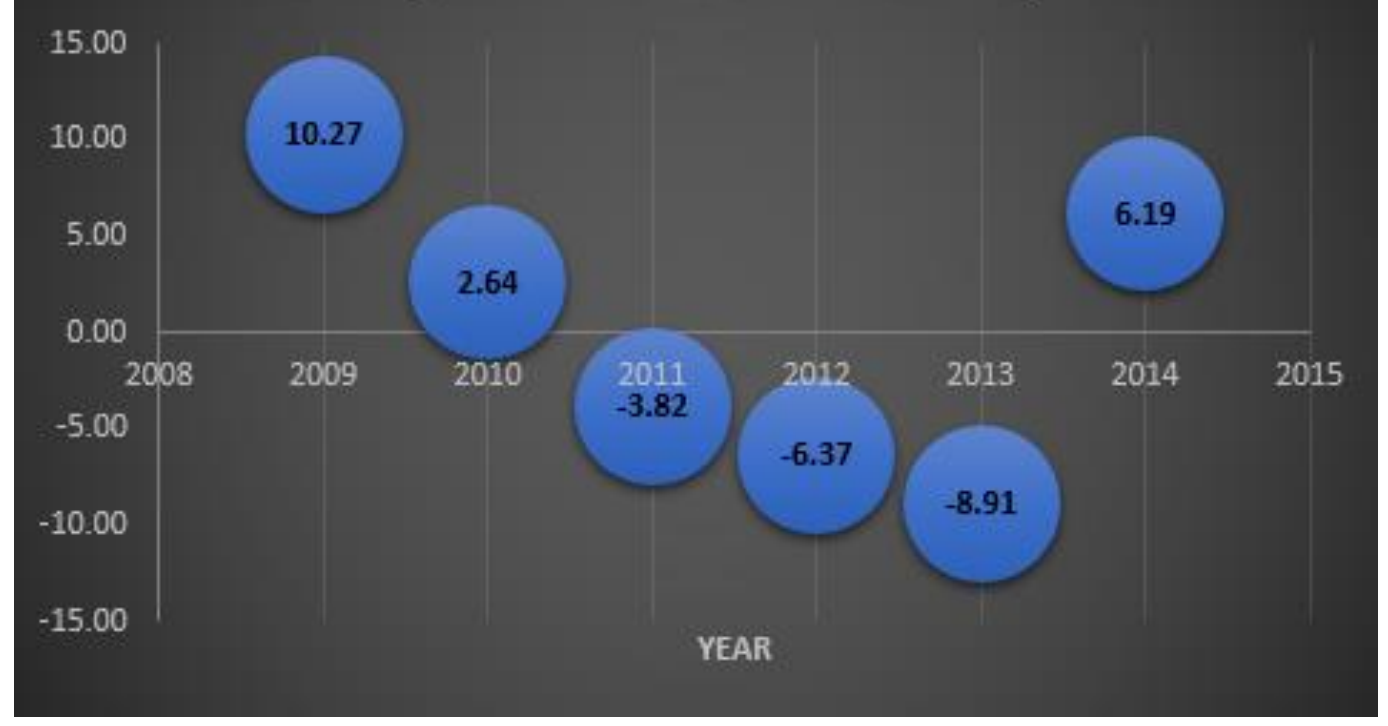

Figure 2 plots the changes of $R B C_{2}$ scores in ASC Topics between 2009-2014. 
TABLE 4

Descriptive Statistics of All Firms

\begin{tabular}{lcrrrrrrr}
\hline \multicolumn{1}{l}{ Panel A: Univariate descriptive statistics for variables of interest } \\
\hline Variable & $\underline{\mathbf{N}}$ & $\underline{\mathbf{M e a n}}$ & $\underline{\mathbf{S . D}}$ & $\underline{\mathbf{M i n}}$ & $\underline{\mathbf{0 . 2 5}}$ & $\underline{\underline{\text { Median }}}$ & $\underline{\mathbf{0 . 7 5}}$ & $\underline{\underline{M a x}}$ \\
\hline LnAF & 1,410 & 15.39 & 0.93 & 13.23 & 14.74 & 15.33 & 16.00 & 18.31 \\
Restatement & 1,410 & 0.08 & 0.27 & 0.00 & 0.00 & 0.00 & 0.00 & 1.00 \\
PSCORE & 1,410 & -48.35 & 31.01 & -319.35 & -58.96 & -45.38 & -30.97 & -0.12 \\
Big_4 & 1,410 & 0.99 & 0.09 & 0.00 & 1.00 & 1.00 & 1.00 & 1.00 \\
LNTA & 1,410 & 9.44 & 1.21 & 5.87 & 8.56 & 9.40 & 10.30 & 13.57 \\
LEV & 1,410 & 1.11 & 3.36 & 0.00 & 0.26 & 0.56 & 1.02 & 38.63 \\
LOSS & 1,410 & 0.06 & 0.24 & 0.00 & 0.00 & 0.00 & 0.00 & 1.00 \\
ROA & 1,410 & 0.07 & 0.06 & -0.16 & 0.04 & 0.07 & 0.10 & 0.33 \\
GEOSEG & 1,410 & 4.17 & 3.81 & 0.00 & 2.00 & 3.00 & 6.00 & 36.00 \\
BUSSEG & 1,410 & 3.17 & 3.02 & 0.00 & 1.00 & 3.00 & 5.00 & 25.00 \\
\hline
\end{tabular}

\begin{tabular}{|c|c|c|c|c|c|c|c|c|c|c|}
\hline \multicolumn{11}{|c|}{ Panel B: Correlation Matrix } \\
\hline & $\operatorname{LnAF}$ & Restate & PSCORE & Big_4 & LNTA & $L E V$ & $L O S S$ & $R O A$ & GEOSEG & BUSSEG \\
\hline $\operatorname{LnAF}$ & & -0.041 & -0.400 & 0.066 & 0.756 & 0.175 & -0.020 & -0.130 & 0.248 & 0.258 \\
\hline Restatement & -0.050 & & -0.007 & 0.028 & -0.031 & 0.016 & -0.043 & 0.024 & -0.018 & -0.031 \\
\hline PSCORE & -0.344 & -0.024 & & -0.016 & -0.420 & -0.232 & -0.042 & 0.267 & -0.066 & -0.138 \\
\hline Big_4 & 0.086 & 0.028 & -0.023 & & 0.066 & 0.028 & -0.009 & 0.021 & 0.073 & 0.037 \\
\hline LNTA & 0.774 & -0.036 & -0.393 & 0.058 & & 0.308 & 0.001 & -0.303 & -0.070 & 0.142 \\
\hline$L E V$ & 0.034 & -0.033 & -0.035 & 0.018 & 0.072 & & 0.057 & -0.388 & -0.276 & 0.049 \\
\hline LOSS & -0.029 & -0.043 & -0.016 & -0.009 & -0.012 & 0.146 & & -0.412 & -0.010 & -0.007 \\
\hline$R O A$ & -0.096 & 0.014 & 0.205 & 0.022 & -0.220 & -0.098 & -0.504 & & 0.211 & -0.135 \\
\hline GEOSEG & 0.263 & -0.031 & -0.017 & 0.059 & 0.046 & -0.045 & -0.011 & 0.134 & & 0.034 \\
\hline BUSSEG & 0.285 & -0.042 & -0.140 & 0.051 & 0.171 & -0.002 & -0.023 & -0.121 & 0.045 & \\
\hline
\end{tabular}




\begin{tabular}{|c|c|c|c|c|c|c|c|c|}
\hline \multicolumn{9}{|c|}{ Panel C: PSCORE descriptive statistics in 2-digit SIC industries } \\
\hline \multicolumn{2}{|r|}{ SIC Industry description } & \multirow{2}{*}{$\begin{array}{r}\mathbf{2 0 0 9} \\
-39.98\end{array}$} & \multirow{2}{*}{$\begin{array}{r}\mathbf{2 0 1 0} \\
-53.31\end{array}$} & \multirow{2}{*}{$\begin{array}{r}\mathbf{2 0 1 1} \\
-63.60\end{array}$} & \multirow{2}{*}{$\begin{array}{c}\mathbf{2 0 1 2} \\
-66.93\end{array}$} & \multirow{2}{*}{$\begin{array}{r}\mathbf{2 0 1 3} \\
-90.37\end{array}$} & \multirow{2}{*}{\begin{tabular}{|c|}
$\mathbf{2 0 1 4}$ \\
-0.5073
\end{tabular}} & \multirow{2}{*}{$\begin{array}{r}\text { Overall } \\
-52.45\end{array}$} \\
\hline 10 & Metal, Mining & & & & & & & \\
\hline 13 & Oil \& Gas Extraction & -43.00 & -47.41 & -53.21 & -55.02 & -54.93 & -53.116 & -51.11 \\
\hline 14 & Nonmetallic Minerals, Except Fuels & -40.93 & -51.27 & -55.43 & -69.84 & -58.41 & -59.603 & -55.91 \\
\hline 15 & General Building Contractors & -30.06 & -35.10 & -49.94 & -41.17 & -40.45 & -38.649 & -39.23 \\
\hline 16 & Heavy Construction, Except Building & -22.91 & -34.16 & -49.95 & -57.53 & -59.09 & -45.813 & -44.91 \\
\hline 20 & Food \& Kindred Products & -29.53 & -41.09 & -56.07 & -58.27 & -66.26 & -58.22 & -51.57 \\
\hline 21 & Tobacco Products & -34.64 & -58.38 & -53.73 & -51.92 & -47.53 & -40.041 & -47.70 \\
\hline 22 & Textile Mill Products & -18.89 & -14.10 & -36.11 & -38.57 & -44.27 & -45.68 & -32.94 \\
\hline 23 & Apparel \& Other Textile Products & -15.11 & -8.77 & -25.76 & -42.96 & -54.31 & -48.084 & -32.50 \\
\hline 25 & Furniture \& Fixtures & -15.54 & -20.54 & -58.56 & -61.55 & -61.02 & -66.496 & -47.28 \\
\hline 26 & Paper \& Allied Products & -39.68 & -56.79 & -53.02 & -56.10 & -52.38 & -53.654 & -51.94 \\
\hline 28 & Chemical \& Allied Products & -28.24 & -38.07 & -52.68 & -56.75 & -57.54 & -53.689 & -47.83 \\
\hline 29 & Petroleum \& Coal Products & -34.94 & -50.30 & -56.13 & -53.25 & -57.89 & -51.921 & -50.74 \\
\hline 30 & Rubber \& Miscellaneous Plastics Products & -13.75 & -19.22 & -49.53 & -56.09 & -67.66 & -59.971 & -44.37 \\
\hline 31 & Leather \& Leather Products & -6.94 & -24.62 & -25.60 & -32.05 & -99.26 & -30.755 & -36.54 \\
\hline 34 & Fabricated Metal Products & -12.83 & -25.78 & -44.42 & -46.20 & -55.43 & -43.757 & -38.07 \\
\hline 35 & Industrial Machinery \& Equipment & -35.01 & -47.12 & -56.92 & -61.95 & -67.21 & -58.007 & -54.37 \\
\hline 36 & Electronic \& Other Electric Equipment & -28.97 & -38.14 & -52.41 & -57.08 & -52.03 & -53.493 & -47.02 \\
\hline 37 & Transportation Equipment & -43.52 & -50.16 & -60.93 & -63.10 & -58.97 & -54.622 & -55.22 \\
\hline 38 & Instruments \& Related Products & -36.82 & -42.00 & -52.94 & -53.86 & -55.10 & -52.175 & -48.82 \\
\hline 40 & Railroad Transportation & -24.32 & -28.72 & -41.66 & -42.30 & -45.61 & -35.776 & -36.40 \\
\hline 42 & Trucking \& Warehousing & -31.62 & -62.34 & -61.13 & -53.29 & -50.38 & -52.481 & -51.87 \\
\hline 44 & Water Transportation & -11.28 & -13.77 & -36.95 & -36.02 & -39.02 & -38.278 & -29.22 \\
\hline 45 & Transportation by Air & -17.98 & -17.19 & -44.07 & -44.30 & -58.22 & -46.756 & -38.09 \\
\hline 47 & Transportation Services & -13.92 & -18.50 & -20.29 & -21.40 & -22.48 & -23.605 & -20.03 \\
\hline 48 & Communications & -38.51 & -41.59 & -54.07 & -51.05 & -51.09 & -43.472 & -46.63 \\
\hline 49 & Electric, Gas, \& Sanitary Services & -59.64 & -88.61 & -99.05 & -94.38 & -86.30 & -91.04 & -86.50 \\
\hline & Wholesale Trade - Durable Goods & -11.89 & -24.78 & -36.04 & -38.03 & -40.26 & -40.106 & -31.85 \\
\hline & Wholesale Trade - Nondurable Goods & -18.02 & -27.40 & -50.21 & -46.96 & -74.31 & -48.992 & -44.32 \\
\hline
\end{tabular}




\begin{tabular}{|c|c|c|c|c|c|c|c|c|}
\hline \multicolumn{9}{|c|}{ Panel C (Continued): PSCORE descriptive statistics in 2-digit SIC industries } \\
\hline SIC & Industry description & 2009 & 2010 & 2011 & 2012 & 2013 & 2014 & Overall \\
\hline 52 & Building Materials \& Gardening Supplies & -16.25 & -17.65 & -30.15 & -28.67 & -27.52 & -25.095 & -24.22 \\
\hline 53 & General Merchandise Stores & -14.35 & -16.27 & -37.10 & -32.26 & -34.55 & -29.108 & -27.27 \\
\hline 54 & Food Stores & -10.20 & -15.86 & -47.41 & -40.45 & -39.57 & -38.035 & -31.92 \\
\hline 55 & Automative Dealers \& Service Stations & -9.48 & -18.18 & -29.82 & -34.07 & -34.82 & -29.569 & -25.99 \\
\hline 56 & Apparel \& Accessory Stores & -13.87 & -14.59 & -40.30 & -40.62 & -41.53 & -37.835 & -31.46 \\
\hline 57 & Furniture \& Homefurnishings Stores & -22.89 & -28.54 & -81.82 & -64.85 & -63.57 & -53.373 & -52.51 \\
\hline 58 & Eating \& Drinking Places & -27.88 & -34.89 & -46.88 & -51.16 & -59.99 & -46.044 & -44.47 \\
\hline 59 & Miscellaneous Retail & -19.07 & -19.63 & -26.87 & -36.00 & -38.08 & -37.553 & -29.53 \\
\hline 67 & Holding \& Other Investment Offices & -36.33 & -49.02 & -58.40 & -51.39 & -51.35 & -0.6227 & -41.18 \\
\hline 72 & Personal Services & -17.18 & -26.86 & -50.50 & -60.31 & -53.67 & -42.143 & -41.78 \\
\hline 73 & Business Services & -28.77 & -30.15 & -51.94 & -54.49 & -57.69 & -52.636 & -45.95 \\
\hline 78 & Motion Pictures & -14.23 & -24.15 & -24.64 & -27.53 & -25.49 & -22.065 & -23.02 \\
\hline 80 & Health Services & -37.99 & -28.00 & -52.96 & -52.17 & -55.02 & -60.9 & -47.84 \\
\hline 87 & Engineering \& Management Services & -8.96 & -15.57 & -37.36 & -37.10 & -53.27 & -37.839 & -31.69 \\
\hline
\end{tabular}


FIGURE 3

Changes of Mean PSCORE

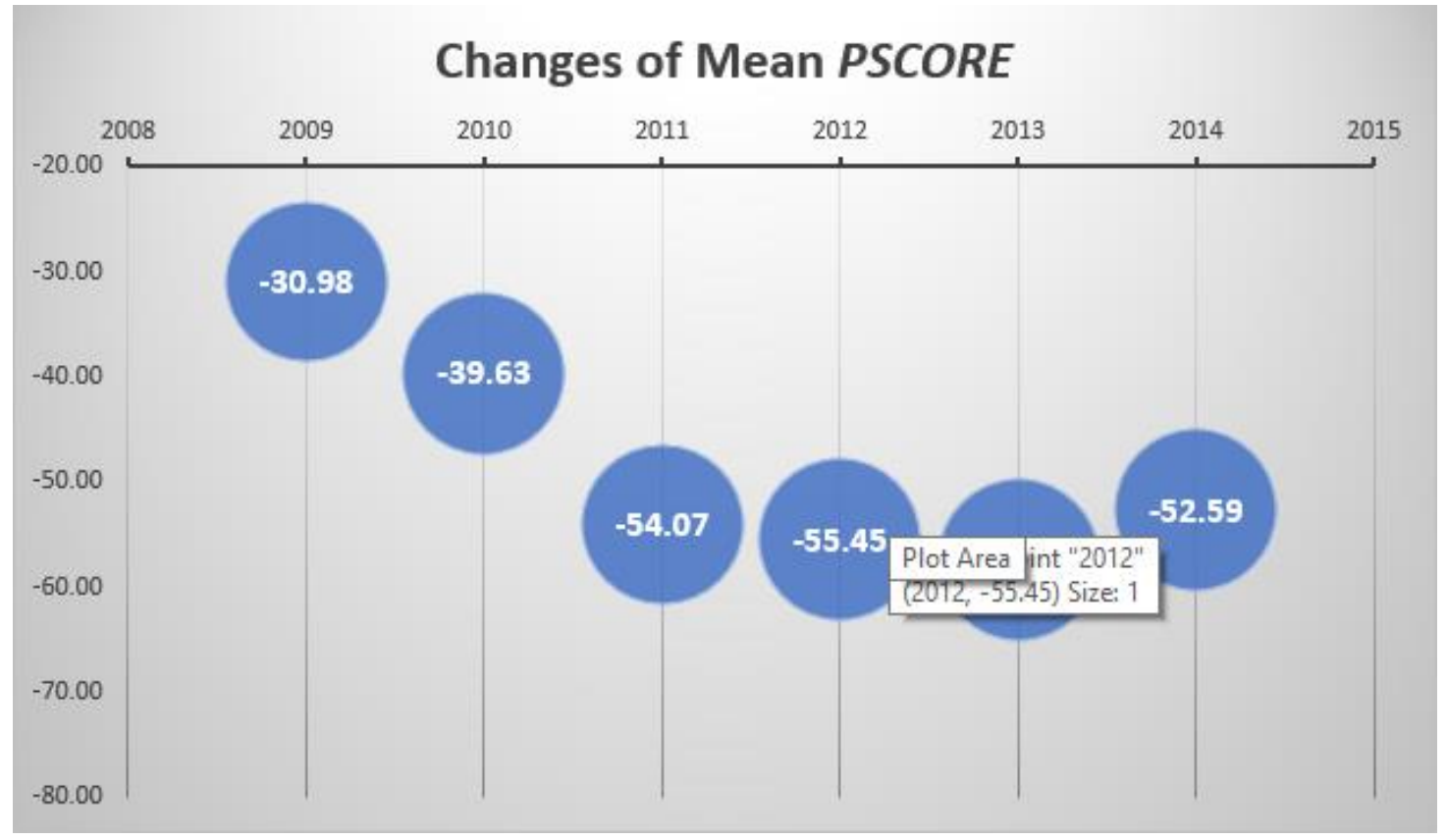

Figure 3 presents the changes of average PSCORE from 2009 to 2014. 
FIGURE 4A

Mean PSCORE by Year in Big 4

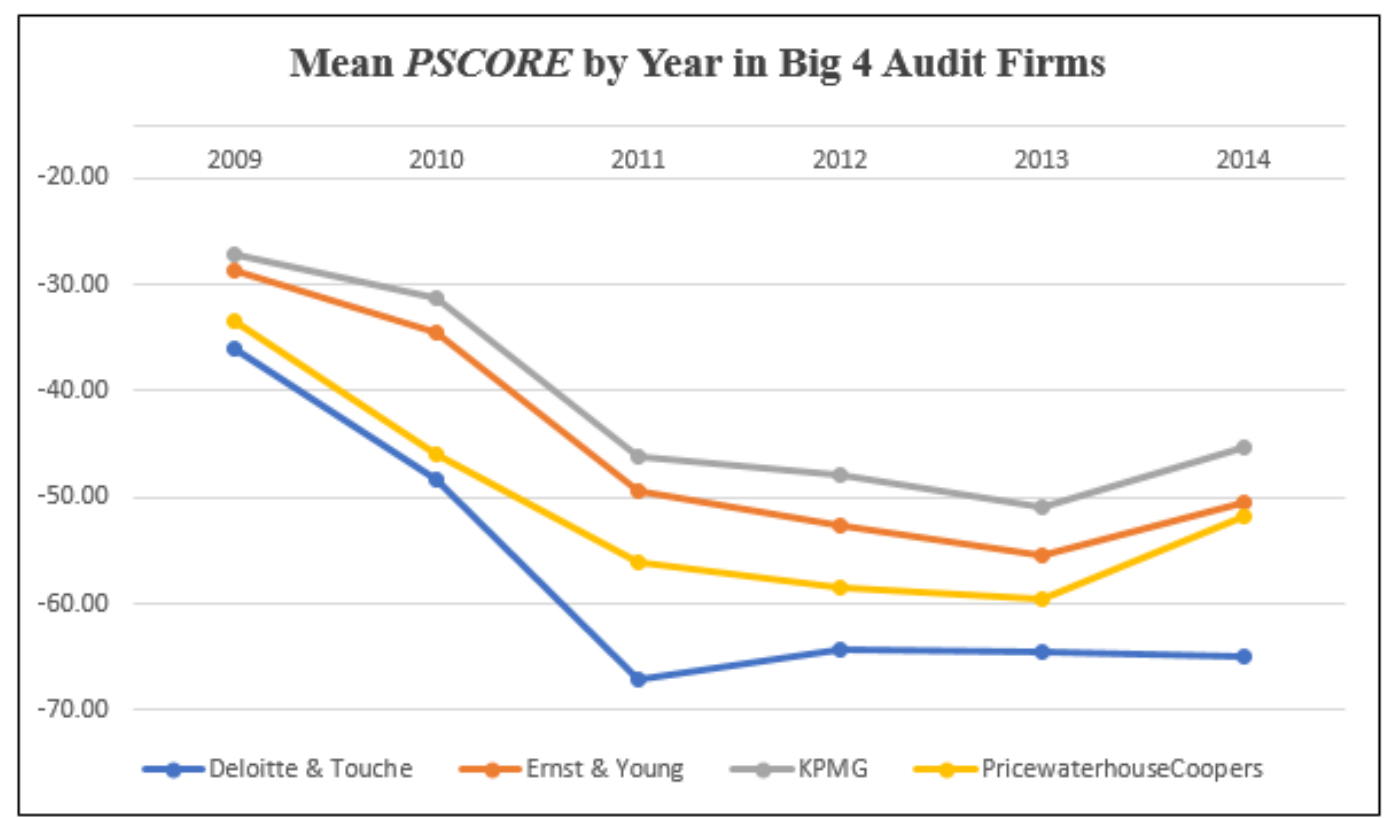

Figure 4A shows average PSCORE in Big 4 audit firms between 2009-2014.

FIGURE 4B

Big 4 Audit Fees by Year

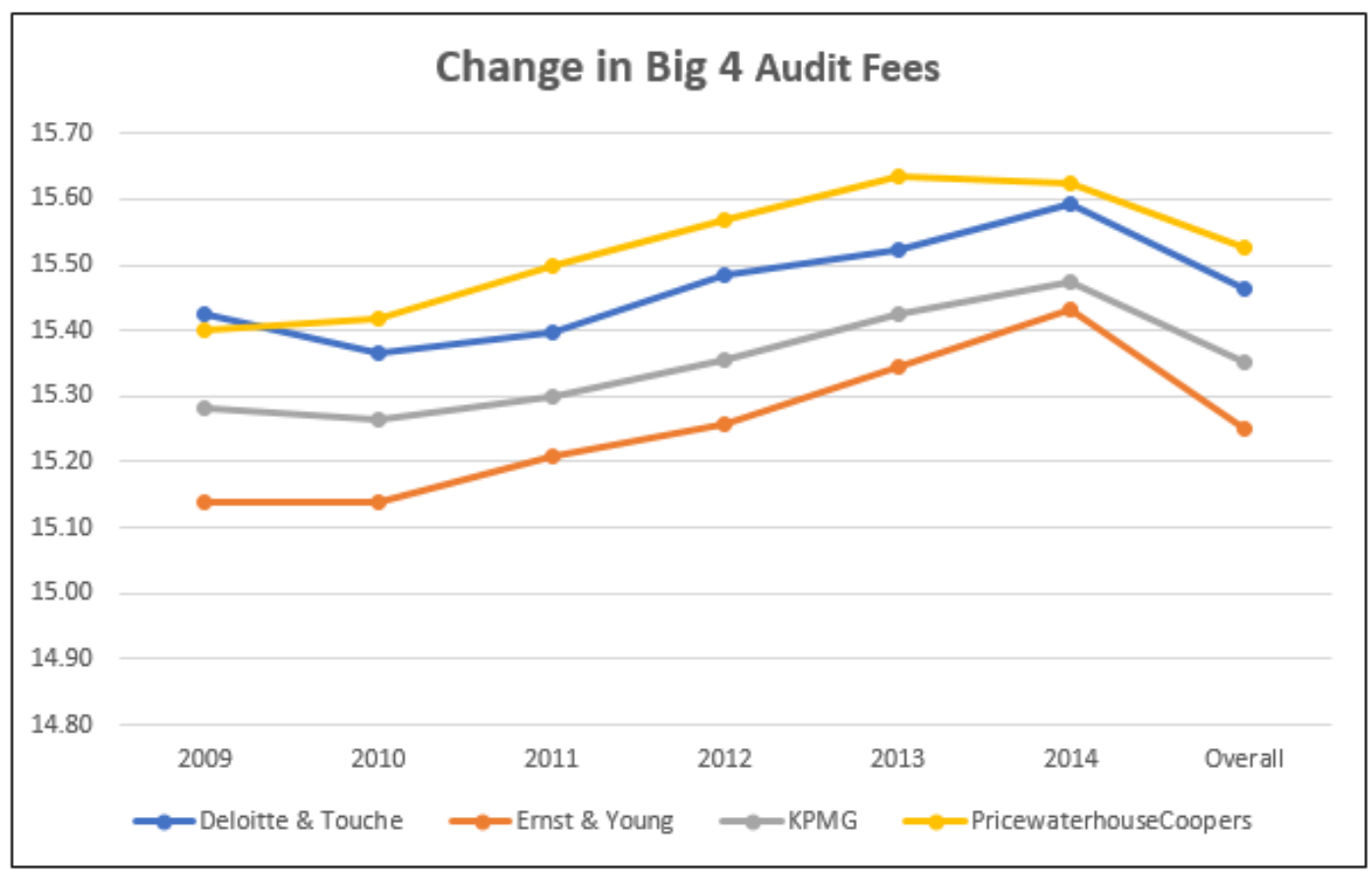

Figure 4B shows audit fees of Big 4 audit firms by year. 
TABLE 5

OLS Regression Results - Audit Fees

$$
\begin{aligned}
L_{n A F_{i t}} & =\beta_{0}+\beta_{1} \text { PSCORE }_{i t}+\beta_{2} \text { BIG }_{4} 4_{i t}+\beta_{3} L N T A_{i t} \\
& +\beta_{4} L E V_{i t}+\beta_{5} \text { LOSS }_{i t}+\beta_{6} \text { ROA }_{i t}+\beta_{7} \text { GEOSEG }_{i t} \\
& +\beta_{8} \text { BUSSEG }_{i t}+\text { Industry/Year FE }+\varepsilon_{i t}
\end{aligned}
$$

\begin{tabular}{|c|c|c|c|c|}
\hline Variable & Coeff. & Beta & \multicolumn{2}{|c|}{ t-statistic } \\
\hline PSCORE & -0.001 & -0.031 & -1.98 & $* *$ \\
\hline Big_4 & 0.037 & 0.004 & 0.28 & \\
\hline LNTA & 0.640 & 0.832 & 52.48 & $* * *$ \\
\hline$L E V$ & -0.005 & -0.017 & -1.34 & \\
\hline LOSS & 0.065 & 0.017 & 1.10 & \\
\hline$R O A$ & 0.407 & 0.026 & 1.56 & \\
\hline GEOSEG & 0.026 & 0.106 & 7.32 & $* * *$ \\
\hline BUSSEG & 0.021 & 0.068 & 5.00 & $* * *$ \\
\hline Intercept & 9.066 & & 36.02 & $* * *$ \\
\hline Year FE & Included & & & \\
\hline Industry FE & Included & & & \\
\hline $\mathrm{N}$ & 1,410 & & & \\
\hline $\mathrm{R}^{2}(\%)$ & $80.49 \%$ & & & \\
\hline
\end{tabular}


TABLE 6

Logistic Regression Results - Restatements

$$
\begin{aligned}
\text { Restatement }_{i t}= & \beta_{0}+\beta_{1} \text { PSCORE }_{i t}+\beta_{2} \text { BIG }_{-} N_{i t}+\beta_{3} B I G_{-} 4_{i t} * \\
& \text { PSCORE }_{i t}+\beta_{4} L N T A_{i t}+\beta_{5} L_{E V_{i t}}+ \\
& \beta_{6} \text { LOSS }_{i t}+\beta_{7} \text { ROA }_{i t}+\beta_{8} G E O S E G_{i t} \\
& +\beta_{9} B U S S E G_{i t}+\text { Industry/Year FE }+\varepsilon_{i t}
\end{aligned}
$$

\begin{tabular}{lccc}
\hline Variable & Coeff. & Beta & t-statistic \\
\hline PSCORE & -0.000 & -0.033 & -1.34 \\
Big_4 & 0.115 & 0.037 & 1.35 \\
BIG4PSCORE & -0.000 & -0.013 & -0.02 \\
LNTA & -0.008 & -0.038 & -1.08 \\
LEV & -0.001 & -0.007 & -0.26 \\
LOSS & -0.034 & -0.030 & -0.90 \\
ROA & 0.069 & 0.015 & 0.41 \\
GEOSEG & -0.001 & -0.012 & -0.38 \\
BUSSEG & -0.003 & -0.033 & -1.12 \\
Intercept & -0.023 & & 0.16 \\
& & & \\
Year FE & Included & & \\
Industry FE & Included & & \\
& & & \\
$\mathrm{N}$ & 1,410 & & \\
$\mathrm{R}^{2}(\%)$ & & & \\
$* * * * * *$ Denote significance at the 1 percent, 5 percent, and 10 percent levels, \\
respectively (two-tailed).
\end{tabular}


TABLE 7

Descriptive Statistics - Timely Loss Recognition

\begin{tabular}{lcrrrrrrr}
\hline Panel A: Mean Variables of Full Sample \\
\hline Variable & $\underline{\mathbf{N}}$ & $\underline{\text { Mean }}$ & $\underline{\mathbf{S . D} .}$ & $\underline{\text { Min }}$ & $\underline{\mathbf{0 . 2 5}}$ & $\underline{\text { Median }}$ & $\underline{\mathbf{0 . 7 5}}$ & $\underline{\text { Max }}$ \\
$X$ & 1,322 & 0.05 & 0.05 & -0.52 & 0.04 & 0.05 & 0.07 & 0.49 \\
$D$ & 1,322 & 0.16 & 0.37 & 0.00 & 0.00 & 0.00 & 0.00 & 1.00 \\
Ret & 1,322 & 0.28 & 0.40 & -0.79 & 0.07 & 0.21 & 0.40 & 3.78 \\
$P S C O R E$ & 1,322 & -49.07 & 31.75 & -319.35 & -59.59 & -45.90 & -31.15 & -0.12 \\
$D^{*}$ Ret & 1,322 & -0.02 & 0.07 & -0.79 & 0.00 & 0.00 & 0.00 & 0.00 \\
RPSCORE & 1,322 & -12.21 & 19.55 & -237.56 & -17.02 & -8.32 & -2.29 & 32.34 \\
DRPSCORE & 1,322 & 0.94 & 3.36 & 0.00 & 0.00 & 0.00 & 0.00 & 32.34 \\
\hline
\end{tabular}

\begin{tabular}{|c|c|c|c|c|c|c|c|}
\hline \multicolumn{8}{|c|}{ Panel B: Correlation Matrix } \\
\hline & $X$ & $D$ & Ret & PSCORE & $D * \operatorname{Ret}$ & RPSCORE & DRPSCORE \\
\hline$X$ & & 0.078 & -0.171 & -0.022 & -0.081 & 0.144 & 0.078 \\
\hline$D$ & 0.048 & & -0.642 & -0.035 & -0.995 & 0.642 & 0.995 \\
\hline Ret & -0.079 & -0.451 & & 0.186 & 0.645 & -0.852 & -0.644 \\
\hline PSCORE & -0.016 & -0.002 & 0.136 & & 0.035 & 0.234 & -0.053 \\
\hline$D * \operatorname{Ret}$ & -0.007 & -0.667 & 0.393 & -0.006 & & -0.644 & -0.999 \\
\hline$R_{e t} * P S C O R E$ & 0.021 & 0.407 & -0.796 & 0.251 & -0.353 & & 0.645 \\
\hline$D^{*} \operatorname{Ret}^{*} P S C O R E$ & 0.013 & 0.634 & -0.364 & -0.094 & -0.897 & 0.361 & \\
\hline
\end{tabular}


TABLE 8

OLS Regression Results - Timely Loss Recognition

$$
\begin{aligned}
E_{i t}= & \beta_{0}+\beta_{1} D_{i t}+\beta_{2} \operatorname{Ret}_{i t}+\beta_{3} P S C O R E_{i t}+\beta_{4} D_{i t} * \operatorname{Ret}_{i t}+ \\
& \beta_{5} \operatorname{Ret}_{i t} * \operatorname{PSCORE}_{i t}+\beta_{6} D_{i t} * \operatorname{Ret}_{i t} * P S C O R E_{i t}+\varepsilon_{i t}
\end{aligned}
$$

\begin{tabular}{|c|c|c|c|c|}
\hline Variable & Coeff. & Beta & \multicolumn{2}{|c|}{ t-statistic } \\
\hline$D$ & 0.007 & 0.054 & 1.33 & \\
\hline Ret & - $\mathbf{0 . 0 3 3}$ & -0.264 & -4.19 & $* * *$ \\
\hline PSCORE & 0.000 & 0.083 & 2.12 & $* *$ \\
\hline$D * \operatorname{Ret}$ & 0.110 & 0.154 & 2.00 & $* *$ \\
\hline $\operatorname{Ret}^{*} \mathrm{PSCORE}$ & - 0.001 & -0.213 & -3.37 & $* * *$ \\
\hline$D * \operatorname{Ret}^{*} P S C O R E$ & 0.002 & 0.099 & 1.39 & \\
\hline Intercept & 0.060 & & 15.73 & $* * *$ \\
\hline Year FE & Included & & & \\
\hline Industry FE & Included & & & \\
\hline $\mathrm{N}$ & 1,322 & & & \\
\hline $\mathrm{R}^{2}(\%)$ & $1.69 \%$ & & & \\
\hline
\end{tabular}




\section{REFERENCES}

Abbott, L.J., Parker, S., and Peters, G. F. 2004. Audit Committee Characteristics and Restatements. Auditing: A Journal of Theory and Practice, 23(1), 69-87.

Agoglia, C. P., Doupnik, T. S., and Tsakumis, G. T. 2011. Principles-based versus rulesbased accounting standards: The influence of standard precision and audit committee strength on financial reporting decisions. The Accounting Review, 86(3), 747-767.

Agrawal, A., and Chadha S. 2005. Corporate Governance and Accounting Scandals. The Journal of Law \& Economics, 48(2), 371-406.

Amer, T., Hackenbrack, K., and Nelson, M. 1994. Between-auditor differences in the interpretation of probability phrases. Auditing: A Journal of Practice \& Theory, 13, 126136.

Archambeault, D. S., Dezoort, F. T., and Hermanson, D. R. 2008. Audit Committee Incentive Compensation and Accounting Restatements. Contemporary Accounting Research, 25(4), 965-92.

Ashbaugh, H., LaFond, R., and Mayhew, B. W. 2003. Do Nonaudit Services Compromise Auditor Independence? Further Evidence. The Accounting Review, 78(3), 611-639.

Ball, R., Kothari, S. P., and Robin, A. 2000. The effect of international institutional factors on properties of accounting earnings. Journal of Accounting and Economics, 29, 1-50.

Ball, R., Robin, A., and Wu, J. S. 2003. Incentives versus standards: properties of accounting income in four East Asian countries. Journal of Accounting and Economics, $36,235-270$.

Barth, M. E., Landsman, W. R., and Lang, M. H. 2008. International Accounting Standards and Accounting Quality. Journal of Accounting Research, 46(3), 467-498.

Bartov, E., Goldberg, S., and Kim, M. 2005. Comparative value relevance among German, US and international accounting standards: a German stock market perspective. Journal of Accounting, Auditing and Finance, 20, 95-119.

Boone, J. P., Linthicum, C. L., and Poe, A. 2013. Characteristics of Accounting Standards and SEC Review Comments. Accounting Horizons, 27(4), 711-736.

Caplan, D., and Kirschenheiter, M. 2004. A Model of Auditing Under Bright-Line Accounting Standards. Journal of Accounting, Auditing \& Finance, 19 (4), 523 - 559.

Chin, C. L., and Chi, H. Y. 2009. Reducing Restatements with Increased Industry Expertise. Contemporary Accounting Research, 26(3), 729-65. 
Cohen, J. R., Krishnamoorthy, G., Peytcheva, M., and Wright, A. M. 2013. How Does the Strength of the Financial Regulatory Regime Influence Auditors' Judgments to Constrain Aggressive Reporting in a Principles-Based Versus Rules-Based Accounting Environment? Accounting Horizons, 27(3), 579-691.

Collins, D. L., Pasewark, W. R., and Riley, M. E. 2012.Financial Reporting Outcomes under Rules-Based and Principles-Based Accounting Standards. Accounting Horizons, 26(4), 681-705.

Congress, 2002. The Sarbanes-Oxley Act of 2002.

Cunningham, L. A. 2007. Prescription to retire the rhetoric of principles-based systems in corporate law, securities regulation, and accounting, a. V and. L. Rev., 60, 1409.

Dechow, P. M. and Skinner, D. J. 2000. Earnings management: Reconciling the views of accounting academics, practitioners, and regulators. Accounting Horizons, 14(2), 235250.

Dechow, P. M., Ge, W., and Schrand, C. 2010. Understanding earnings quality: A review of the proxies, their determinants and their consequences. Journal of Accounting and Economics, 50(2), 344-401.

DiPiazza, S., McDonnell, D., Samyn, F., Flynn, T., Quigley, J., and Turley, J. 2008. Global dialogue with capital market stakeholders: A report from the CEOs of the international audit networks. New York: Global Public Policy Symposium.

Donelson, D. C., McInnis, J. M., and Mergenthaler, R. D. 2012. Rules-based accounting standards and litigation. The Accounting Review, 87(4), 1247-1279.

Donelson, D., McInnis, J., and Mergenthaler, R. 2016. Explaining Rules-Based Characteristics in U.S. GAAP: Theories and Evidence. Journal of Accounting Research, 54(3), 827-861.

Financial Accounting Standards Board. 2002. Principles-based approach to standards setting. 2007. FACTS about FASB.

Folsom, D., Hribar, P., Mergenthaler, R., and Peterson, K. 2017. Principles-Based Standards and Earnings Attributes. Management Science, 63(8), 2592-2615.

Francis, J., LaFond, R., Olsson, P., Schipper, K. 2005. The market pricing of accruals quality. Journal of Accounting and Economics, 39, 295-327.

Francis, F. R., and Martin, X. 2009. Acquisition profitability and timely loss recognition. Journal of Accounting and Economics, 49, 161-178. 
Fung, S. Y. K., Gul, F. A., and Krishnan, J. 2012. City-Level Auditor Industry Specialization, Economies of Scale, and Audit Pricing. The Accounting Review, 87(4), 1281-1307.

Gao, P., Sapra, H., and Xue, H. 2017. A Model of Principles-Based Vs. Rules-Based Standards. Working paper, NYU Stern and Chicago Booth.

Grenier, J. H., Pomeroy, B., and Stern, M. T. 2015. The Effects of Accounting Standard Precision, Auditor Task Expertise, and Judgment Frameworks on Audit Firm Litigation Exposure. Contemporary Accounting Research, 32(1), 336-357.

Healy, P. M. and Wahlen, J. M. 1999. A Review of the earnings management literature and its implications for standard setting. Accounting Horizons, 13(4), 365-383.

Henderson, D. and O'Brien, P. C. 2017. The standard-setters' toolkit: can principles prevail over bright lines? Review of Accounting Studies, 22, 644-676.

Herz, R. H. 2003. A year of challenge and change for the FASB. Accounting Horizons, $17,247-255$.

Imhoff, E. A., and Thomas J. K. 1988. Economic consequences of accounting standards: The lease disclosure rule change. Journal of Accounting and Economics, 10 (4), 277-310.

Jamal, K., and Tan, H. T. 2010. Joint effects of principles-based versus rules-based standards and auditor type in constraining financial managers' aggressive reporting. The Accounting Review, 85(4), 1325-1346.

Kadous, K., and Mercer, M. 2012. Can Reporting Norms Create a Safe Harbor? Jury Verdicts against Auditors under Precise and Imprecise Accounting Standard. The Accounting Review, 87(2), 565-587.

Kaplow, L. 2000. General characteristics of rules. In Encyclopedia of Law and Economics, Volume V. The Economics of Crime and Litigation, 502-528.

Kim, J. B., and Shi, H. 2012. Voluntary IFRS adoption, analyst coverage, and information quality: International evidence. Journal of International Accounting Research, 11(1), 4576.

Kinney, W., Palmrose, Z., and Scholz, S. 2004. Auditor independence, non-audit services, and restatements: Was the U.S. government right? Journal of Accounting Research 42 (3), 561-588.

La Porta, R., Lopez-de-Silanes, F., Shleifer, A., and Vishny, R. W. 1998. Law and Finance. Journal of Political Economy, 106(6), 1113-1155. 
Leuz., C., Nanda., D., and Wysocki, P. D. 2003. Earnings management and investor protection: an international comparison. Journal of Financial Economics, 69, 505-527.

Maines, L. A., Bartov, E., Fairfield, P., Hirst, D. E., Iannaconi, T. E., Mallett, R., Schrand, C. M., Skinner, D. J., and Vincent, L. 2003. Evaluating Concepts-Based vs. Rules-Based Approaches to Standard Setting. Accounting Horizons, 17(1), 73-89.

Melone, A. M. 2004. United States Accounting Standards - Rules or Principles? The Devil Is Not in the Details. U. Miami L. Rev, 58, 1161-1224.

Mergenthaler, R. D. 2011. Principles-Based versus Rules-Based Standards and Accounting Irregularities. Working paper, University of Iowa.

Mihalcea, R. and Tarau, P. 2004. TextRank: Bringing Order into Texts, Conference on Empirical Methods in Natural Language Processing (EMNLP 2004), Barcelona, Spain.

Nelson, M. W., Elliott, J. A., and Tarpley, R. L. 2002. Evidence from auditors about managers' and auditors' earnings management decisions. The Accounting Review, 77(s1), 175-202.

Nelson, M. 2003. Behavioral Evidence on the Effects of Principles-and Rules-Based Standards. Accounting Horizons, 17 (1), 91-104.

Nobes, C. W. 2004. On accounting classification and the international harmonization debate. Accounting, Organizations and Society, 29(2), 189-200.

Numan, W., and Wilekens, M. 2012. An empirical test of spatial competition in the audit market. Journal of Accounting and Economics, 53, 450-465.

Peytcheva, M., Wright, A. M., and Majoor B. 2014. The Impact of Principles-Based versus Rules-Based Accounting Standards on Auditors' Motivations and Evidence Demands. Behavioral Research in Accounting, 26(2), 51-72.

Rose, S., Engel, D., Cramer, N., and Cowley, W. 2010. Automatic Keyword Extraction from Individual Documents. Text Mining: Applications and Theory. 1 - 20.

Schipper, K. 2003. Principles-based Accounting Standards. Accounting Horizons, 17 (1), 61- 72 .

Securities and Exchange Commission SEC. 2003. Study pursuant to Section 108(d) of the Sarbanes-Oxley Act of 2002 on the adoption by the United States Financial Reporting System of a principles-based accounting system. SEC Staff Report. Washington DC: SEC. 
. 2008. Roadmap for the potential use of financial statements prepared in accordance with International Financial Reporting Standards by U.S. Issuers, United States Securities and Exchange Commission, Washington, DC: SEC.

. 2012. Workplan for the Consideration of Incorporating International Financial Reporting Standards into the Financial Reporting System of U.S. Issuers: Final Staff Report. Washington DC: SEC.

Sennetti, J. T., Becker, C. P., and Lawrence, H. J. 2011. Does the Change To PrinciplesBased Accounting Increase Juror Assessments Of Auditor Liability. Advances in Accounting Behavioral Research, 14, 165-189

Zhang, J. 2008.The contracting benefits of accounting conservatism to lenders and borrowers. Journal of Accounting and Economics, 45, 27-54. 


\section{Appendix A}

\section{Variable Definitions}

$\underline{\text { Variable }}$

Dependent Variables:

$L n A F_{i t}$

Restatements $_{i t}$

$E_{i t}$

\section{Other Variables:}

PSCORE $_{i t}$

$B I G_{-} 4_{i t}$

LNTA $_{\text {it }}$

$L E V_{i t}$

$\operatorname{LOSS}_{i t}$

$R O A_{i t}$

GEOSEG $_{i t}$

$B U S S E G_{i t}$

$D_{i t}$

$\operatorname{Ret}_{i t}$ $\underline{\text { Definition }}$

$=$ nature logarithm of audit fees for company $i$ in year $t$;

$=1$ if company $i$ 's audited financial statements in year $t$ are subsequently restated, and 0 otherwise;

$=$ earnings for firm $i$ in year $t$, deflated by opening stock price $P_{t-1}$;

$=$ product of relative importance score of firm $i$ for standard $s$ in year $t$ and the standard $s$ ' corresponding $R B C_{1}$ score in year $t$;

$=1$ if company $i$ is audited by a Big 4 firm in year $\mathrm{t}$, and 0 otherwise;

$=$ natural logarithm of total assets for company $i$ in year $t$;

$=$ total liability in year $t$ divided by total assets, winsorized at 1 and 99 percent;

$=1$ if company $i$ reports a loss in year $t$, and 0 otherwise;

$=$ income before extraordinary items in year $t$ divided by total assets, winsorized at 1 and 99 percent;

$=$ the number of geographic segments for firm $i$ in year $t$;

$=$ the number of business segments for firm $i$ in year $t$;

$=1$ if firm $i$ reports a loss $\left(\operatorname{Ret}_{i t}<0\right)$ in year $t$, and 0 otherwise;

$=$ return on firm $i$ from 9 months before the fiscal yearend $t$ to three months after the fiscal year-end $t$. 


\section{Appendix B \\ Indicators of Rules-based Characteristics}

\section{Bright-line thresholds}

A bright-line is defined as a numeric threshold that delineates appropriate accounting treatments. The keywords used to identify bright-lines are: criteri*, condition*, provision*, require*, and percent*. ${ }^{*}$ I read the surrounding paragraph to determine the presences of these numeric thresholds. The sum of total numeric bright-line thresholds for each standard is counted.

\section{Scope and Legacy Exceptions}

Scope and legacy exceptions lead to inconsistent accounting treatment for similar transactions. The keywords used to identify scope and legacy exceptions are: not subject, not consider*, exclusion*, exempt*, scope, and does not apply. I read the surrounding paragraph to determine the presences of these exceptions. The sum of total numeric brightline thresholds for each standard is counted.

\section{Large-volumes of Implementation Guidance}

Both principles- and rules-based standards contain some level of implementation guidance. To identify large volumes of interpretive guidance as rules-based characteristics, the number of "interpretive pronouncements" from each accounting standard is counted. Then, all standards are ranked by the number of "interpretive pronouncements". Only the standards in the top decile are classified as large volumes of implementation guidance.

\section{High-level of Details}

First, the level of detail in each U.S. standard is identified by a word count. I then rank all standards by their total number of words. Only the ones in the top decile are classified as high-level of detail standards. Following Mergenthaler (2011), background and basis for conclusions sections in the word count are excluded.

\footnotetext{
19 The keywords with * represent root words; all stemming words are also captured by textual analysis. For example, the search for keyword "criteri"” will also return stemming words such as "criteria" and "criterion".
} 


\section{Appendix C}

Keyword Extraction by ASC Topic

\begin{tabular}{|c|c|c|c|c|c|}
\hline ASC & Standard & Keyword 1 & Keyword 2 & Keyword 3 & Keyword 4 \\
\hline 105 & FAS168 & $\begin{array}{l}\text { accounting standards } \\
\text { codification }\end{array}$ & gaap hierarchy & nongovernmental entities & authoritative \\
\hline 205 & ASC_205_30 & $\begin{array}{l}\text { compara* financial } \\
\text { statement* }\end{array}$ & $\begin{array}{l}\text { presentation and } \\
\text { disclosure }\end{array}$ & discontinued operation & $\begin{array}{l}\text { liquidation basis of } \\
\text { accounting }\end{array}$ \\
\hline 210 & ASC_210_20 & $\begin{array}{l}\text { classification of current } \\
\text { assets (liabilities) }\end{array}$ & offset* & repurchase agreement* & $\begin{array}{l}\text { statement of financial } \\
\text { position }\end{array}$ \\
\hline 220 & FAS130 & comprehensive income & & & \\
\hline 225 & APB9 & discontinued operations & extraordinary items & disposal /5/ segment & unusual /5/ infrequent $*$ \\
\hline 230 & FAS95 & $\begin{array}{l}\text { operating (investing) } \\
\text { (financing) activities }\end{array}$ & $\begin{array}{l}\text { cash receipts and } \\
\text { payments }\end{array}$ & (in)direct method & \\
\hline 235 & APB22 & $\begin{array}{l}\text { disclosure of accounting } \\
\text { policies }\end{array}$ & & & \\
\hline 250 & FAS154 & $\begin{array}{l}\text { change in accounting } \\
\text { principle }\end{array}$ & $\begin{array}{l}\text { change in accounting } \\
\text { estimate }\end{array}$ & change in reporting entity & $\begin{array}{l}\text { error } / 5 / \text { previously issued } \\
\text { financial statement }\end{array}$ \\
\hline 255 & FAS89 & Changing Prices & five-year summary & translate-restate & restate-translate \\
\hline 260 & FAS128 & $\begin{array}{l}\text { basic (dilutive) earnings } \\
\text { per share (EPS) }\end{array}$ & $\begin{array}{l}\text { computations } / 5 / \\
\text { earnings per share } \\
\text { (EPS) }\end{array}$ & & \\
\hline 270 & APB28 & $\begin{array}{l}\text { (summarized) interim } \\
\text { financial }\end{array}$ & less than a full year & interim period* & \\
\hline 272 & ASC_272_10 & $\begin{array}{l}\text { limited liability entit*/ } \\
\text { compan* }\end{array}$ & limited personal liability & & \\
\hline 275 & ASC_275_10 & inherent & estimat* & assumption* & $\begin{array}{l}\text { assess } * / 5 / \text { risk }^{*} \text { and } \\
\text { uncertaint* }\end{array}$ \\
\hline 280 & FAS131 & operating segments & aggregation criteria & components & allocate $/ 5 /$ resources \\
\hline 310 & ASC_310_10 & trouble $*$ debt restruc $*$ & debt $/ 5 /$ restruc $*$ & debt restruct $/ 5 /$ settle $*$ & debt $/ 5 /$ modifi $*$ \\
\hline 320 & FAS115 & $\begin{array}{l}\text { available-for-sale } / 5 / \\
\text { securit* }\end{array}$ & trading $/ 5 /$ securit & $\begin{array}{l}\text { Held-to-maturity /5/ } \\
\text { securit* }\end{array}$ & $\begin{array}{l}\text { other than temporary } \\
\text { impairment } / 10 / \text { investment }\end{array}$ \\
\hline 323 & APB18 & equity method & significant influence & share of earnings & share of loss(es) \\
\hline
\end{tabular}


Appendix C (Continued)

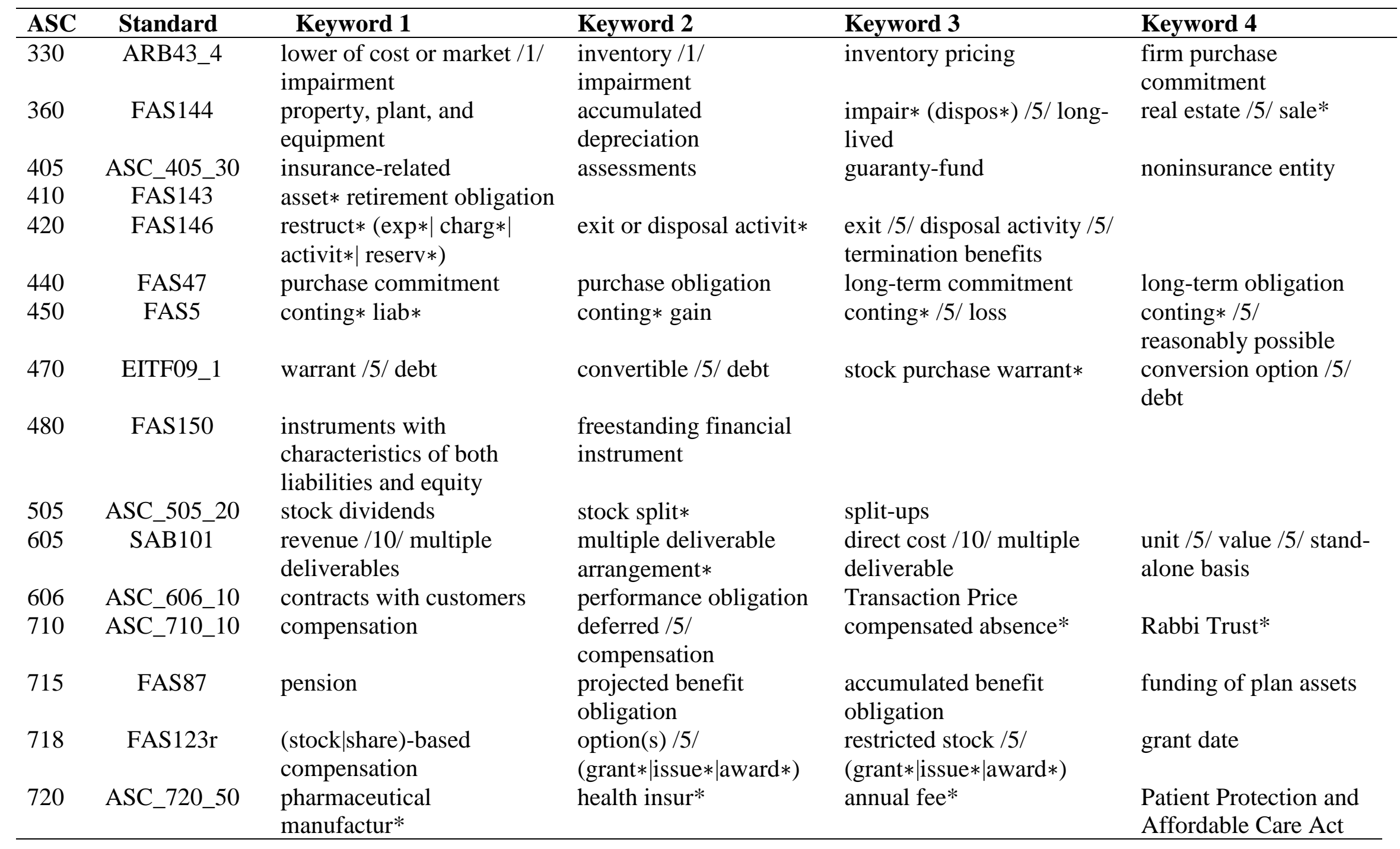




\section{Appendix C (Continued)}

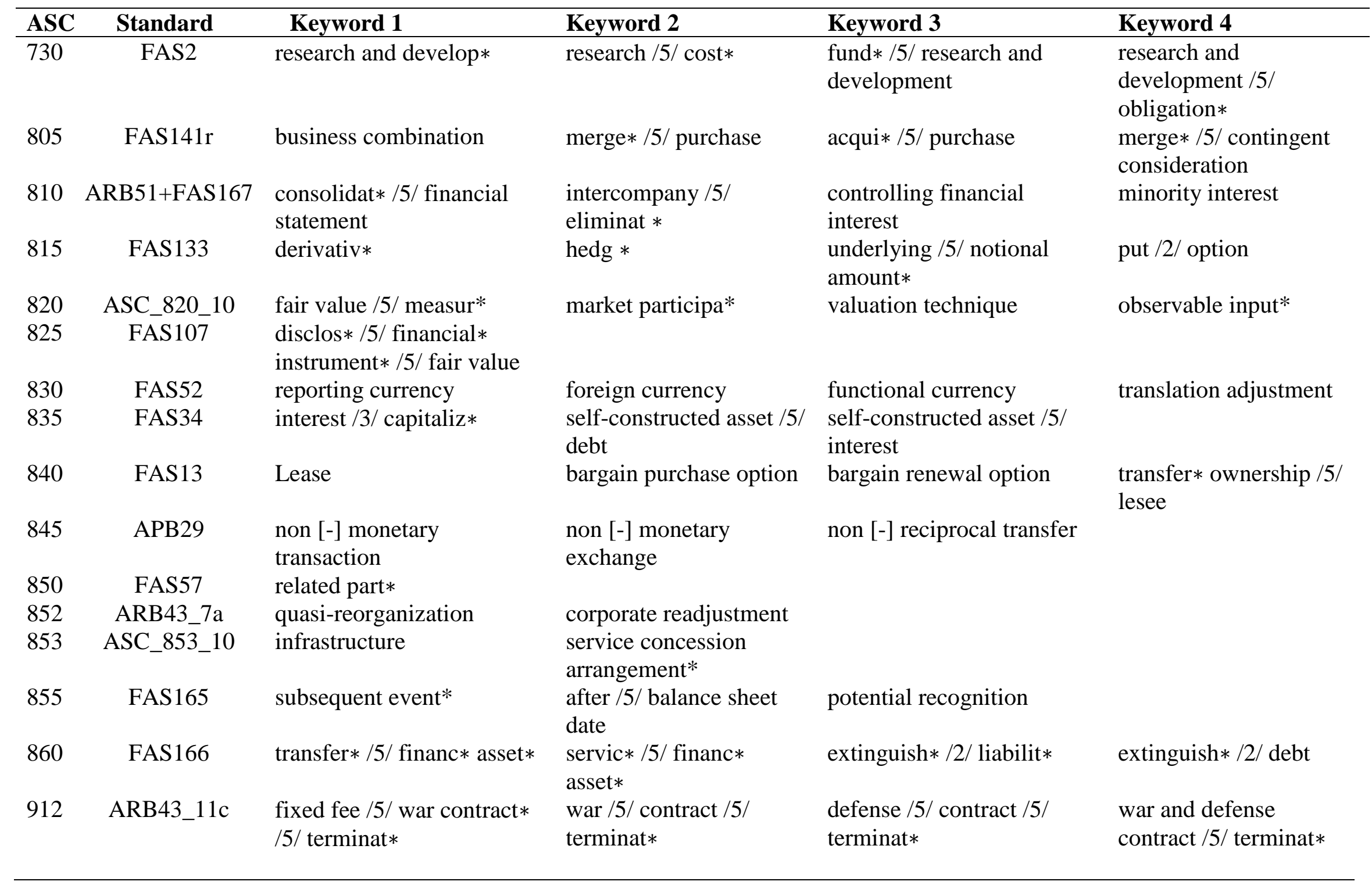


Appendix C (Continued)

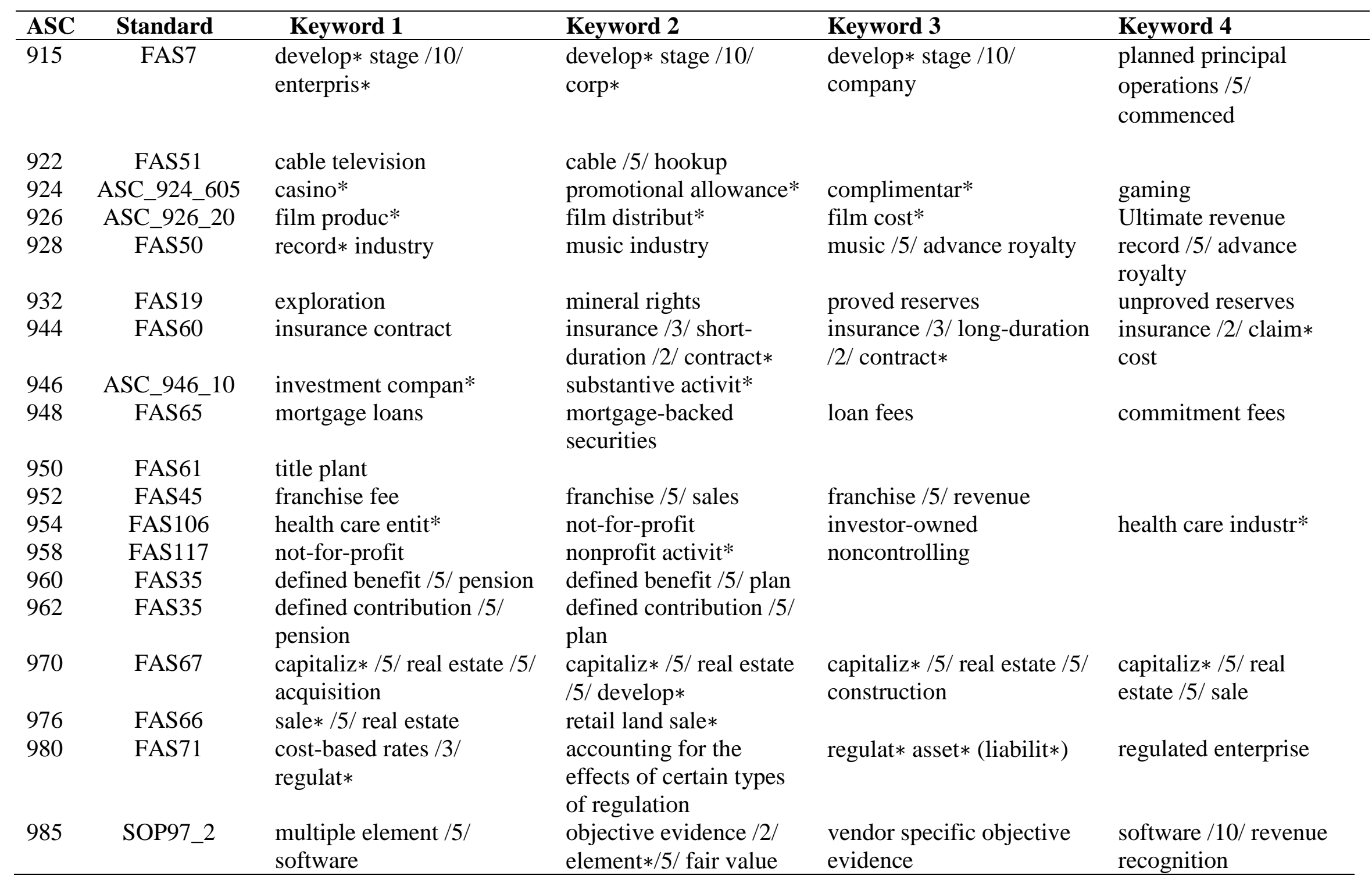


VITA

RAN LING

Born, Nanjing, Jiangsu

2009-2012

B.S., Accounting

M.S., Accounting

University of Kentucky

Lexington, Kentucky

2014-2018

Ph.D. Business Administration

Florida International University

Miami, Florida

Teaching and Research Assistant

Florida International University

Miami, Florida

\section{PUBLICATIONS AND PRESENTATIONS}

Ling, Ran, (2017), The Effect of the PCAOB's Restrictions on Auditor-Provided Tax Services on Audit Quality, Earnings Quality, and Tax Avoidance. (Working paper presented at the Spring 2017 FIU School of Accounting Research Workshop) 